\title{
9. X-RAY MINERALOGY STUDIES, LEG 42A, DEEP SEA DRILLING PROJECT, MEDITERRANEAN SEA
}

\author{
Frédéric Mélières, Université Pierre et Marie Curie, Paris, France \\ Hervé Chamley, Université de Luminy, Marseille, France \\ Francis Coumes, Elfaquitaine, Pau, France \\ and \\ Pierre Rouge, Compagnie Française des Pétroles, Bordeaux, France
}

\section{INTRODUCTION}

This report synthesizes $\mathrm{X}$-ray mineralogy data from Sites $371,372,373,374,375,376,377$, and 378 on Leg $42 \mathrm{~A}$ in the Mediterranean Sea. Before the cruise, a very careful statement on the routine sampling policy was established by the scientific party, making available one sample per section of core for routine X-ray mineralogy analysis. In this way, around 450 samples were taken, the study of which was shared among different laboratories:

- bulk X-ray mineralogy: all sites (F. Mélières)

- clay mineralogy: Sites 374,375 , and 376 (H. Chamley)

- clay mineralogy: Site 372 (F. Coumes)

- clay mineralogy: Sites 371, 373, 377, and 378 (P. Rouge)

The upper Miocene evaporites, encountered at six sites, were not sampled for routine X-ray mineralogy analysis because of the highly diversified lithologies found. It was decided that the study of the evaporitic facies (mainly gypsum, anhydrite and halite) would be carried out with an essentially petrographic approach (Garrison et al., this volume).

Here we present information on the methods used by the different laboratories, a site-by-site discussion of the results, and comparisons between sites in chronologic sequence.

\section{METHODS}

\section{Bulk X-ray Mineralogy: All Sites}

The method used, basically operating on non-oriented powder with the use of an internal standard for quantitative determinations, is described elsewhere (Mélières, 1974). A resume of the basic steps follows.

The samples are manually roughly ground in an agate mortar, without any pretreatment (such as removing salts by washing in distilled water ${ }^{1}$ ). After being oven-dried at $40^{\circ} \mathrm{C}, 50 \mathrm{mg}$ of internal standard (sodium fluoride) are mixed with $250 \mathrm{mg}$ of sediment by grinding in the mortar. The mixture is then

\footnotetext{
${ }^{1}$ Consequently, halite reported on analytical data does not exist as a mineral in the sediment; it results from evaporation of interstitial water when the samples are dried.
}

mounted in a rotating sample holder (Mélières, 1973), the speed of which $(10 \mathrm{rev} / \mathrm{sec})$ insures a good reproducibility of the diffracted peak intensities. Two identical Siemens diffractometers, equipped with fine focus copper tubes, are used to run the X-ray diffraction scans. $\mathrm{CuK} \alpha$ radiation is isolated by a nickel filter. The geometry of the X-ray beam is determined by a $0.5^{\circ}$ entering slit, a $0.2 \mathrm{~mm}$ receiving slit, and a frontal knife. The X-ray source intensity is set in order to obtain all the peaks of the constituents (including the internal standard, but omitting the clay minerals), in the best recording conditions. The first scan is then recorded $\left(15^{\circ}\right.$ to $\left.45^{\circ} 2 \theta\right)$ at $1^{\circ} 2 \theta / \mathrm{min}$. A second scan is run for clay minerals $\left(2^{\circ}\right.$ to $\left.17^{\circ} 2 \theta\right)$ under the same conditions but with appropriate gain, depending on the abundance of these minerals in the sample. The third is a slow scan $\left(0.5^{\circ} 2 \mathrm{~g} / \mathrm{min}\right.$ or less $)$ resolving the doublet kaolinite $(002) /$ chlorite $(004)\left(24^{\circ}\right.$ to $\left.26^{\circ} 2 \theta\right)$. After the sample, in its holder, is exposed to a current of ethylene-glycol aerosol for five minutes, to expand the smectite minerals, a fourth scan (with the same conditions as the second one) is run.

The identification of minerals is carried out by reference to standard diffractograms made in the laboratory on pure natural constituents, and, if necessary, with ASTM data and classical handbooks (Brown, 1963; Borg and Smith, 1969).

The quantitative analysis is carried out using calibrated curves giving the mass ratio (given mineral versus internal standard) from the peak intensities ratio. All these curves were prepared in the laboratory using the classical procedure of artificial mixtures (Klug and Alexander, 1967). Depending on minerals, three kinds of measurement of peak intensities are used: (a) for minerals well crystallized and known to be constant in crystallinity (detrital quartz and feldspar, heavy minerals, internal standard, etc...), only the peak height above the background is used; (b) for minerals well crystallized, but offering various degrees of crystallinity such as carbonates, both peak height and width at half-height are used (two entries in the calibrated curve); (c) for minerals more or less well crystallized (clay minerals, opal-CT), the weighted peak area above the background is exclusively used. The amounts of clay minerals are estimated on the glycolated diffractogram. The $10 \AA$ peak is used for illite; the $17 \AA$ peak is used for smectite (this includes 
part of the expandable irregular mixed layer). The $7 \AA$ peak yields the total amount of chlorite + kaolinite, the balance between these minerals being made using the peaks height ratio, at, respectively, $3.54 \AA$ and $3.58 \AA$, according to the Biscaye (1964) method. Amounts of irregular mixed-layer (mainly illite-semectite) are estimated from the area above the background between the $10 \AA$ illite peak and that of smectite at $17 \AA$. This procedure in fact underestimates the true amount of the mixed-layer, because the expandable part of these minerals is more or less incorporated in the $17 \AA$ peak area through the ethylene-glycol treatment. The precision of the quantitative measurement ranges from $5 \%$ to $15 \%$ relative, and depends mainly on the nature of the minerals.

Data concerning the amorphous material content are not reported here because of their insignificance.

The amorphous material content can actually be estimated subtracting the total of all crystallized constituents from 100. In fact, in the hemipelagic sediments of the Mediterranean Sea, mainly consisting of detrital silicates and/or biogenic carbonates, the amorphous material content is usually low (below $10 \%$ ). In such a case, the amorphous material content value has a range of error which is often greater than the value itself; for instance, if the total of crystallized constituents is $93 \% \pm 15 \%$, the resulting amorphous material content will be $7 \% \pm 15 \%$, which lacks significance. For this reason, the percentages of total crystallized constituents are summed to $100 \%$.

\section{Clay Mineralogy: Sites 371, 373, 377, and 378}

The samples are mixed with distilled water for 10 hours, and then are decarbonated in $10 / N$ hydrochloric acid. The excess acid is removed by successive centrifugations. The less than $2 \mu \mathrm{m}$ fraction is collected by decantation employing Stockes' law to calculate settling times, and then oriented aggregates are made on glass slides. A Philips X-ray diffractometer with copper Ni-filtered radiation is used to run three scans as follows: (a) from $2^{\circ}$ to $22^{\circ} 2 \theta\left(8^{\circ} / \mathrm{min}\right)$ on natural sample; (b) from $2^{\circ}$ to $22^{\circ} 2 \theta\left(8^{\circ} / \mathrm{min}\right)$ on glycolated sample; and (c) from $24^{\circ}$ to $26^{\circ} 2 \theta\left(2^{\circ} \% \mathrm{~min}\right)$ on natural sample. Quantitative determinations are carried out using peak heights above the background; the amount of each mineral is considered to be directly proportional to the peak height. The $10 \AA$ peak (natural sample) is used for illite and the $14 \AA$ peak (natural sample) for smectite, eventually corrected for chlorite influence, deduced from the $14 \AA$ peak on glycolated sample. The amount of irregular mixed-layer (illitesmectite) is estimated by the difference of diagram traces between "natural" and "glycol" samples, between $11 \AA$ and $13 \AA$. The $7 \AA$ peak gives the total kaolinite + chlorite. The ratio of these two minerals being deduced from the ratio of the peak heights at $3.58 \AA$ and $3.54 \AA$, respectively. The total of percentages is summed to $100 \%$.

\section{Clay Mineralogy: Site 372}

The method and diffractometer used are very similar to that employed at Sites 371, 373, 377, and 378 .
Minor differences are: (a) clay mineral analysis is performed on the less than $5 \mu \mathrm{m}$ fraction (oriented aggregates); (b) the speed of the X-ray diffraction scans is $2^{\circ} 2 \theta / \mathrm{min}$; and (c) the peak heights used for quantitative estimates, are corrected by classical proportional factors (Johns et al., 1954).

\section{Clay Mineralogy: Sites 374, 375, and 376}

The sample preparation is similar to that above. Both oriented aggregates and oriented pastes are made from the less than $2 \mu \mathrm{m}$ fraction. A CGR Theta 60 diffractometer (copper radiation focused by a quartz curved-crystal monochromator) is used to run the X-ray diffraction scans at $1^{\circ} 2 \theta / \mathrm{min}$. A receiving slit of $1.25 \mathrm{~mm}$ is used for a better determination of mixedlayer minerals. Beside the ethylene-glycol treatment (expansion of smectites), a hydrazine-hydrate treatment is used to characterize the kaolin minerals. The heat treatment consists of two hours at $490^{\circ} \mathrm{C}$. Semiquantitative evaluations are based on the peak heights and areas; smectite and attapulgite are corrected in addition to peak height, and well-crystallized kaolinite is corrected in diminution with regard to middle crystalized illite or chlorite. The balance between chlorite and kaolinite is made from peak heights ratio ( $3.54 \AA$ and $3.58 \AA$, respectively). When this ratio is 1 , the amount of chlorite is assumed to be two times that of kaolinite.

Slight, but unavoidable, discrepancies are to be expected in the quantitative data, since this analytical work was carried out by a team working at several laboratories.

\section{RESULTS AND DISCUSSION}

The analytical data discussed here are listed in Appendix III (this volume). They are presented here as mineralogical logs for each site in Figures 2 to 9. Figure 1 shows the location of the Leg 42A drill sites. The geodynamic conclusions tentatively inferred from the minerolgical data are obviously "monochromatic" and therefore need to be compared with the other sedimentological data (petrography, geochemistry, micropaleontology).

\section{Site 371}

Site 371 is located on the southern edge of the Balearic Abyssal Plain, about $90 \mathrm{~km}$ north of the Algerian Shelf, in 2792 meters of water, and on a slight knoll. The hole penetrated more than 500 meters of hemipelagic Plio-Quaternary sediments, in which only seven cores were taken, and was terminated at 551 meters in the upper Miocene evaporitic facies (Core 8). Thirty-five samples were submitted for X-ray analysis (Figure 2).

The recovered evaporitic sequence consists of 2 meters of homogeneous brown dolomitic marls, barren of indigenous microfossils (its Messinian age is therefore inferred), topped by 1 meter of hard white anhydrite displaying a "chicken-wire" texture, and interpreted as a subaerial (sabkha) deposit (Garrison et al., this volume). The mineralogy of these brown dolomitic marls is characterized by a relatively high 


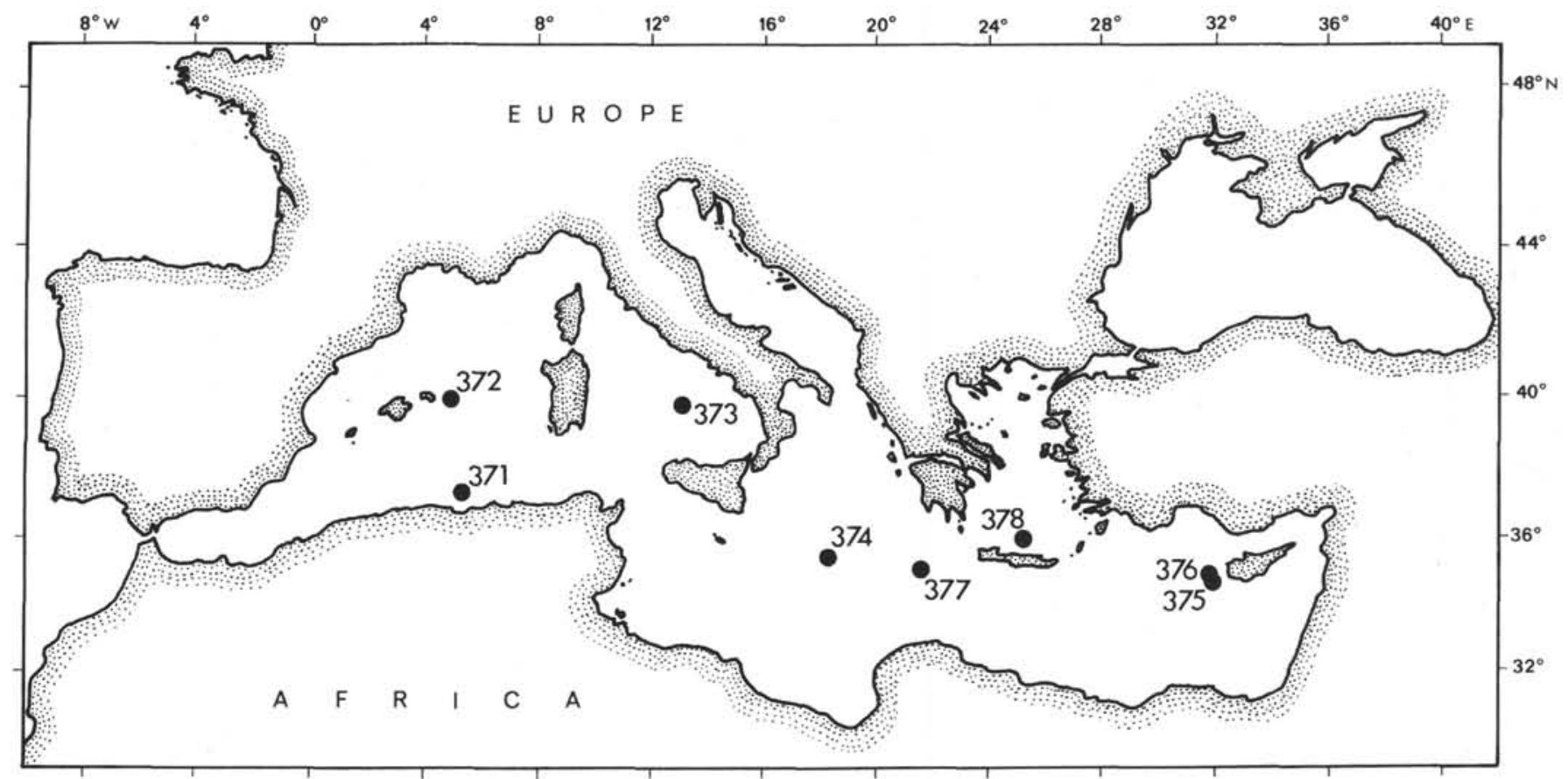

Figure 1. Location of Leg $42 \mathrm{~A}$ drill sites.

terrigenous detrital content (quartz + feldspar $=35 \%$ to $40 \%$ ) which, in the absence of turbidites, suggests the proximity of the sources of the terrigenous material. The clay mineral assemblage consists of illite, irregular mixed-layer illite-smectite, chlorite, and kaolinite. The absence of smectite indicates that the neighboring North African landmasses did not act as source for this mineral at that time. This is in good agreement with the fact that, in Algeria, the Messinian sediments of the Chelif basin ( $500 \mathrm{~km}$ west of Site 371$)$ are characterized by a very low smectite content in the less than 2 $\mu \mathrm{m}$ fraction (Chamley et al., this volume). Therefore the absence of smectite in the Messinian sediments of the Algerian area is amazing since this mineral is believed to have been extensively produced under an arid climate in the poorly drained soils of the Messinian landscape (Chamley et al., this volume). The carbonate fraction consists of approximately equal amounts of calcite (10\% to $15 \%)$ and dolomite (13\% to $15 \%)$. Calcite represents tests of organisms reworked from the Cretaceous and the Paleogene. Dolomite is calcium-rich $\left(\mathrm{Ca}_{55}\right)$ and therefore is probably authigenic or early diagenetic, which is not surprising in such an evaporitic environment. These features suggest that the late Miocene landscape consisted of very shallow basins with scant communication with the open sea.

In contrast to the upper Miocene sediments, the hemipelagic muds of the overlying lower Pliocene (Cores 7,6 , and 5) are characterized by a lower terrigenous coarse material content (quartz + feldspar $=20 \%$ ), a much lower dolomite content ( $1 \%$ to $5 \%$ ), and a higher calcite content (25\% to $45 \%)$. The total amount of clay minerals in the bulk also increases significantly, although the relative composition of the clay fraction remains approximately the same. No traces of smectite can be detected in the clay mineral assemblage. These observations suggest (a) that the sources of detrital material were more distant, and (b) that the circulation of the water masses became well established, allowing a pronounced development of a marine calcareous biogenic productivity. The increase of the water column height would have been more likely due to a moderate raising of sea level rather than to sinking of the sea floor, because in the latter case a coarser terrigenous input (quartz + feldspar) would probably have been present owing to the proximity of the North African landmasses.

The entire upper Pliocene and Quaternary section (Core 4 to 1) consists of calcareous muds with sandy beds and laminae. It is characterized by a remarkably uniform mineralogy, suggesting that the sources of sediments remain constant during all this period. The coarse terrigenous content (quartz + feldspar) however is slightly higher in Cores 3 and 4 (25\% mean value) than in Core 5 . This, together with the presence of sandy laminae and turbidites in Section 2 of Core 3, could suggest a deepening of the basin, which would have begun in the upper Pliocene (between Core 5 and Core 4). The slight but uniform decrease in calcite content (calcareous biogenic production) could also be related to such a progressive deepening (dissolution), although this calcite decrease could be explained by some change in the ecology of the biota, or by an increase in terrigenous material input.

\section{Resume}

a) At the end of the Messinian: landscape consisting of very shallow ponds where subaqueous (dolomitic marls) to subaerial (anhydrite) deposits were deposited; proximity of landmasses suggested by high coarse terrigenous material input. 
F. MÉliÈRES, H. CHAMLEY, F. COUMES, P. ROUGE

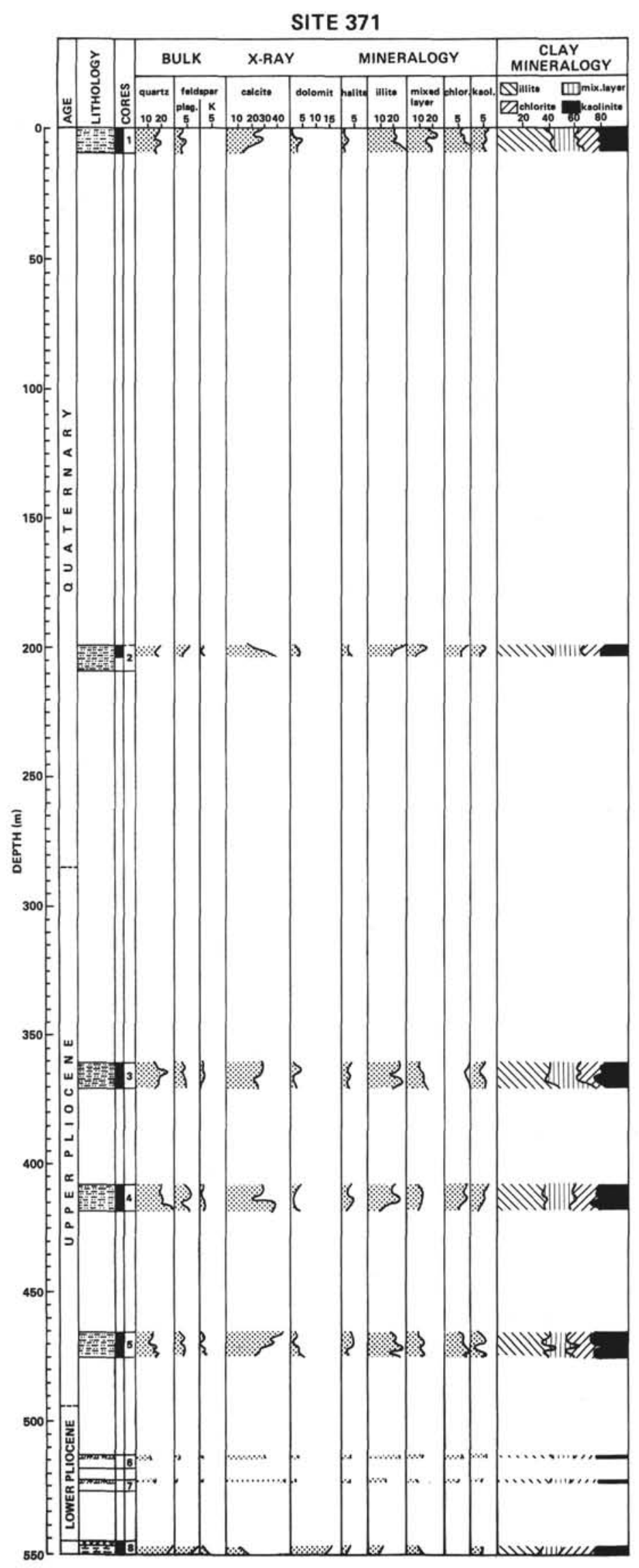

Figure 2. X-ray mineralogy data, Site 371. 
b) Lower Pliocene: marine waters infill the area (raising sea level), supplying optimal conditions for calcareous biogenic production.

c) Middle Pliocene: probable deepening of the area.

d) Since the middle Pliocene: probable increase of the depth of water by continuous lowering of the sea floor, until reaching its present condition.

\section{Site 372}

Site 372 is located at the base of the Balearic Slope, $35 \mathrm{~km}$ east-northeast off the Menorca Shelf, in 2699 meters of water. The hole penetrated a 885 -meter section, half of which was continuously cored. Four lithologic units were distinguished. Lithologic Unit I (Cores 1 to 3 ) consists of Plio-Pleistocene nannofossil marls. Lithologic Unit II (Core 4 to Core 9, Section 2) is a 50 -meter-thick evaporitic sequence (laminated gypsum and dolomitic marls). It represents a part of the Upper Member of the Messinian evaporites (Mauffret et al., 1973) pinching out on the pre-Messinian sediments of the Menorca Rise. Unit III (Core 9, Section 2 to Core 33, Section 3) consists of lower Tortonian to upper Burdigalian nannofossil marls to marlstones. Unit IV (Core 33, Section 4 to Core 46) consists of Burdigalian clayey mudstones, which were deposited with a high sedimentation rate (see Chapter 3, Site Report, this volume). Two-hundred fourteen samples were submitted for X-ray analysis (Figure 3 ).

The mineralogy of Unit IV is remarkably uniform. It consists mainly of an important terrigenous input (70\% of the sediment), a modest carbonate fraction ( $20 \%$ to $25 \%$ ), and opal-CT ( $5 \%$ to $10 \%$ ). The terrigenous fraction is composed of approximately $20 \%$ quartz + feldspar and $50 \%$ clay minerals dominated by the association illite $(25 \%$ to $30 \%)+$ chlorite $(10 \%)$ (both well crystallized), and smectite $(10 \%)^{2}$. The carbonate fraction is composed of calcite $(20 \%)$ and dolomite, the amount of which varies significantly along the sedimentary column. The percentages of this latter mineral range from few percent ( $2 \%$ to $5 \%$ ) in Cores 35,37 , 41,42 , and 43 , up to $15 \%$ in Cores $34,38,39,40$, and even higher values ( $32 \%$ in Core 44 , Section 4 ). Consequently, the calcite/dolomite ratio offers values much lower than that characterizing the recent "normal marine" sedimentation in the western Mediterranean Basin (values ranging from 15 to 20 ) as can be seen at Site 371 and in other Plio-Quaternary deep-sea sections. A diagenetic origin, after burial, seems to be unlikely for this because of the randomness of the calcite/ dolomite ratio variation. The nearness of Jurassic dolomites at Menorca (Bourrouilh, 1973) could suggest a detrital origin for the dolomite of Unit IV. Such an ex-

\footnotetext{
${ }^{2}$ Smectite, visible on the bulk X-ray mineralogy but not apparent on the clay mineralogy column (Figure 3 ), consists of poorly crystallized material giving a bump on the diffractogram (bulk natural sample) between $12 \AA$ and $15 \AA$, but expanding completely to $17 \AA$ (well-defined peak) after ethylene-glycol treatment. These structures are considered as irregular mixed-layer illite-smectite by the clay mineral analyst. They probably are partially illite derived.
}

planation could be supported by the striking correlation between dolomite and quartz + feldspar in Core 44 , although it is not apparent in the other cores. In this hypothesis, the dolomite should be stoichiometric as the Jurassic one, but unfortunately this is not always the case, especially for Core 44 in which the dolomite is partly calcium rich. The problem of the dolomite of Unit IV is probably complex and needs further mineralogical investigation, particularly on the nature of the dolomite. The relatively low calcite content can be explained in terms of dilution of the carbonaceous biogenic production by the important terrigeneous input, which is in good agreement with the high sedimentation rate of the Unit IV. The presence of opal (low cristobalite, or opal-CT in the sense of Jones and Segnit, 1971 ) is easily understood as a product of recrystallization of previously dissolved tests of radiolarians, which are common in the sediments of the Unit IV (see Site Report, Chapter 3). The development of radiolarians in the waters of the basin during this period implies the availability of free silica, which could have been supplied by a volcanic activity. In fact, such an activity is known in this area during the Burdigalian (Mauffret et al., 1973). At some $200 \mathrm{~km}$ meters west-northwest of Site 372 , Hole 123 or Leg 13 penetrated a volcano whose products gave ages ranging from 19 to 22 m.y. (Ferrara et al., 1973).

A major break in the mineralogy within Section 3 of Core 33 separates Unit IV from the overlying Unit III. This occurs at 18.5 m.y. (N6-N7). It is characterized by (a) a sudden decrease in the amount of the terrigeneous material content (quartz + feldspar + clay) which drops from $70 \%$ to $40 \%$ of the sediment, although its relative constitution remains approximately the same (except for a slight increase in the smectite content to ranges of $40 \%$ to $60 \%$. Traces of kaolinite appear in the upper part of this unit. The increase in calcite content probably results from the decrease of the terrigenous input which is confirmed by the sedimentation rate in Unit III which is lower than in Unit IV. Therefore, it can be inferred that the calcareous biogenic productivity is the same in Unit III as in Unit IV. The sudden decrease in supply of terrigenous material, together with an increase in the content of the finest particles (smectite), suggests that the hydrodynamism became rather subdued, in this part of the basin. This change could have been controlled by a tectonic event such as the development of a change in threshold. This hypothesis would be supported by the interruption of the volcanic activity acting as the source of free silica (disappearance of opal-CT). In such a case, this could have marked the end of the rifting of the Balearic Margin. Another possible cause of the change of the hydrodynamism could have been the Langhian transgression (Bourrouilh, 1973). In this hypothesis, the association clinoptilolite + smectite, occurring in the lower part of the Unit III (mainly Cores 28, 29, and 30 ) could be interpreted as resulting from the erosion of volcanic material previously deposited ashore during a phase of rifting. The dolomite content in Unit III is very low ( $1 \%$ to $3 \%$ ) and the calcite/dolomite ra- 
F. MÉLIÈRES, H. CHAMLEY, F. COUMES, P. ROUGE

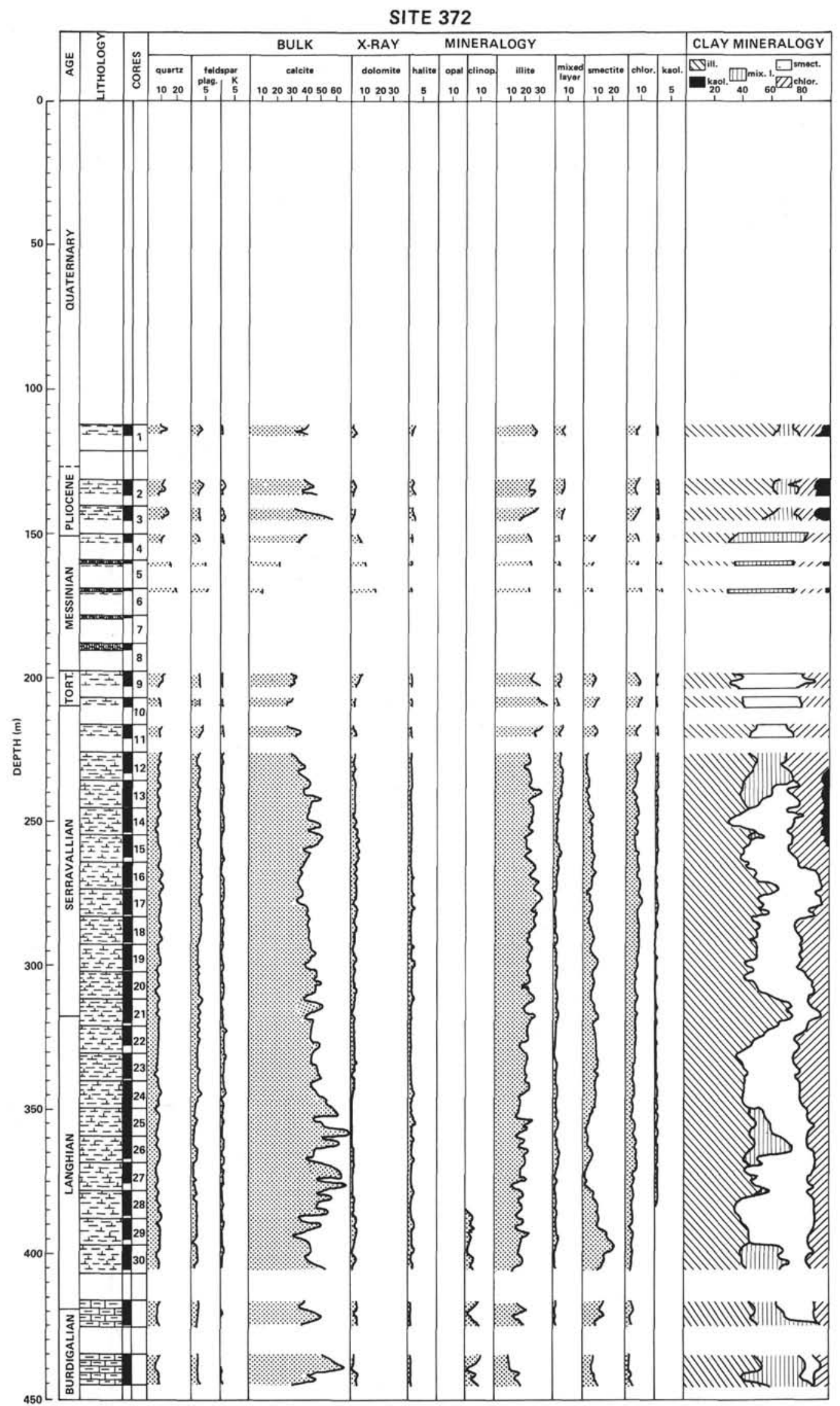

Figure 3. X-ray mineralogy data, Site 372. 
SITE 372

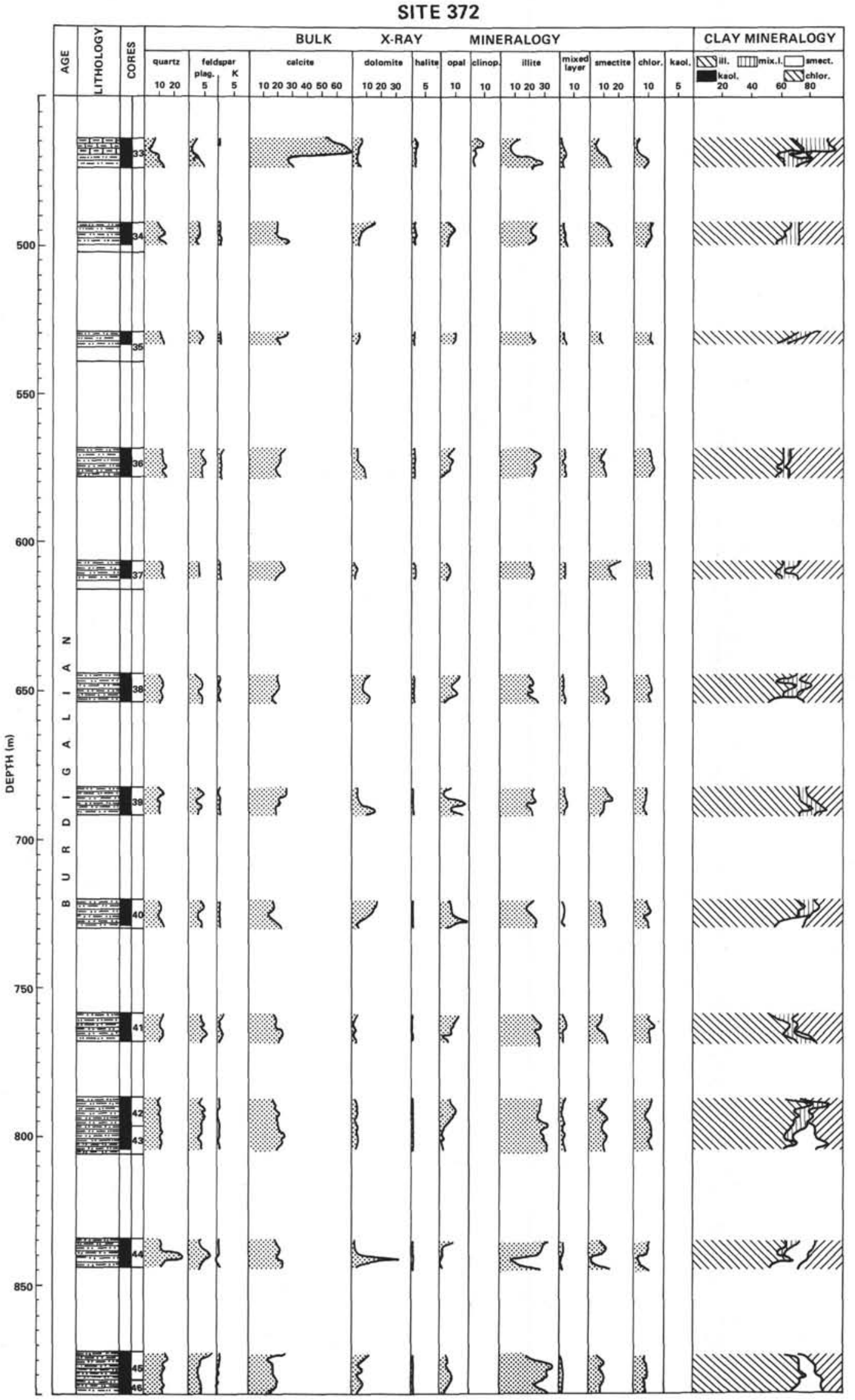

Figure 3. (Continued). 
tio is therefore very different from that of Unit IV, being similar to that of sediments settled in "normal marine" conditions. In the uppermost part of Unit III (Core 9), one notes a very slight increase in both quartz and dolomite content towards the top of the core, which could be interpreted as a trend toward more restricted conditions. The dramatic change in the faunal assemblage occurring in Core 9, Section 2 at 45 $\mathrm{cm}$, indicates a sudden transition from normal marine lower middle bathyal conditions (below) to shallow water lagoonal environment (above), is not noticeably recorded in the mineralogy. A detailed X-ray mineralogy study of Core 9 (Sections 1 and 2) was carried out on a set of narrowly spaced samples (Mélières, this volume). All of Core 9 (except four small pieces of laminated gypsum, topping the sediment of Section 1, which are a drilling artifact) belongs mineralogically to Unit III.

In Unit II (Messinian evaporites), the recovery was extremely poor and only four samples were submitted for X-ray analysis. The nannofossil marls interbedded with laminated gypsum are characterized by a quartz + feldspar content somewhat higher than in the underlying pre-Messinian sediments, suggesting that the sources of at least part of this detrital material were now probably closer to the depositional area (Site 372). This terrigenous fraction shows a marked decrease towards the top of the unit. The clay minerals do not change significantly either in the percentages recorded or in their relative compositions. The calcite content is low ( $10 \%$ in Core 6 ), but increases towards the top of the unit (35\% in Core 4$)$. In contrast, the dolomite content is relatively high ( $17 \%$ in Core 6$)$ and displays an opposite trend (5\% in Core 4 ). This dolomite actually consists of a mixture, in approximately equal amounts, of a stoichiometric dolomite, thought to be detrital from Jurassic dolomites of Menorca, and a calcium-rich dolomite $\left(\mathrm{Ca}_{54}\right)$, which is probably authigenic in a restricted environment. These features confirm that the Messinian evaporites were deposited in a restricted environment unfavorable to the biota (low calcite content in the sediment). The reason for this restriction is probably due to a drop in sea level which caused an increase in the terrigenous detrital input on the margin of the basin; and Site 372 is actually in such a physiographic position. However, this drop was probably not sufficient to isolate the area completely from the open sea as it is shown by the stability of the clay mineral input. In the less than $5 \mu \mathrm{m}$ fraction, the clay mineral assemblage is not significantly different from that of the pre-Messiniam. However, it cannot be excluded that the clay minerals of the Messinian marls could have been reworked from the pre-Messinian sediments, which were exposed to air by the lowering of the sea level.

The mineralogy of the nannofossil marls of Unit 1 (Pleistocene and a condensed section of Pliocene) also offers many similarities to that of the pre-Messinian sediments, confirming that sedimentation, after the Messinian event, returned to normal marine conditions.
This return is associated with changes in the mineralogy towards the top of the Unit II, confirming that the Messinian section penetrated at Site 372 belongs to the Upper Member of the Messinian evaporites. However three significant differences in Unit III are noted in Unit I: (a) the quartz + feldspar content is slightly higher, (b) there is a marked increase in illite (the coarsest among the clay minerals) in the fine fraction, and (c) the smectite (the finest among the clay minerals) disappears completely from the clay assemblage. This could be interpreted as resulting from the establishment of a new hydrodynamic regime, characterized by stronger currents than those prevailing during the deposition of the sediments of Unit III. This hypothesis is supported by the presence of numerous sandy layers within the nannofossil marls of Unit I, and by the condensed nature of the Pliocene section, suggesting that some periods of non-deposition or of submarine erosion took place at that time. This new hydrodynamic regime is probably related to a deepening of the basin. Unfortunately, no information is available from Hole 372 on the Quaternary history of the area.

\section{Resume}

a) Burdigalian: fast infilling of a subsiding basin limited by fault blocks of the Balearic rifted margin (Biju-Duval et al., this volume). Infilling by fine terrigenous detrital material (clay minerals dominant) probably of Alpine origin (association illite-chlorite). Marine environment with free silica available (radiolarians diagentically yield opal-CT) probably provided by volcanic activity.

b) Upper Burdigalian (limit N6-N7: 18.5 m.y. B.P.): sudden decrease of the infilling rate of the basin, thought to be controlled by some tectonic activity possibly related to the end of the Burdigalian volcanism. Establishment of rather calm conditions of marine sedimentation persisting from the uppermost Burdigalian until at least the lower Tortonian.

c) After an erosional gap (about 5 m.y.), probably related to a marked drop in sea level, the Upper Member of the Messinian evaporites is deposited in restricted shallow subaqueous environment.

d) Re-establishment of "normal marine" conditions within the Pliocene and setting up of a new and active hydrodynamic regime as a probable consequence of the deepening of the basin.

\section{Hole 373A}

Hole $373 \mathrm{~A}$ is located on the flank of a seamount in the central Tyrrhenian Abyssal Plain, in 3517 meters of water. A Plio-Quaternary sequence of nannofossil marls, zeolite marls, and volcanic ashes overlies a basaltic complex of calcareousle-cemented basalt breccias and flow basalts. The hole was terminated at 457.5 meters. Only 10 samples from Cores 1 and 2 were submitted for X-ray analysis (Figure 4).

The mineralogy of the sediments of Core 1 (Quaternary) displays numerous variations depending on the different types of sediments encountered. The nanno- 
SITE 373

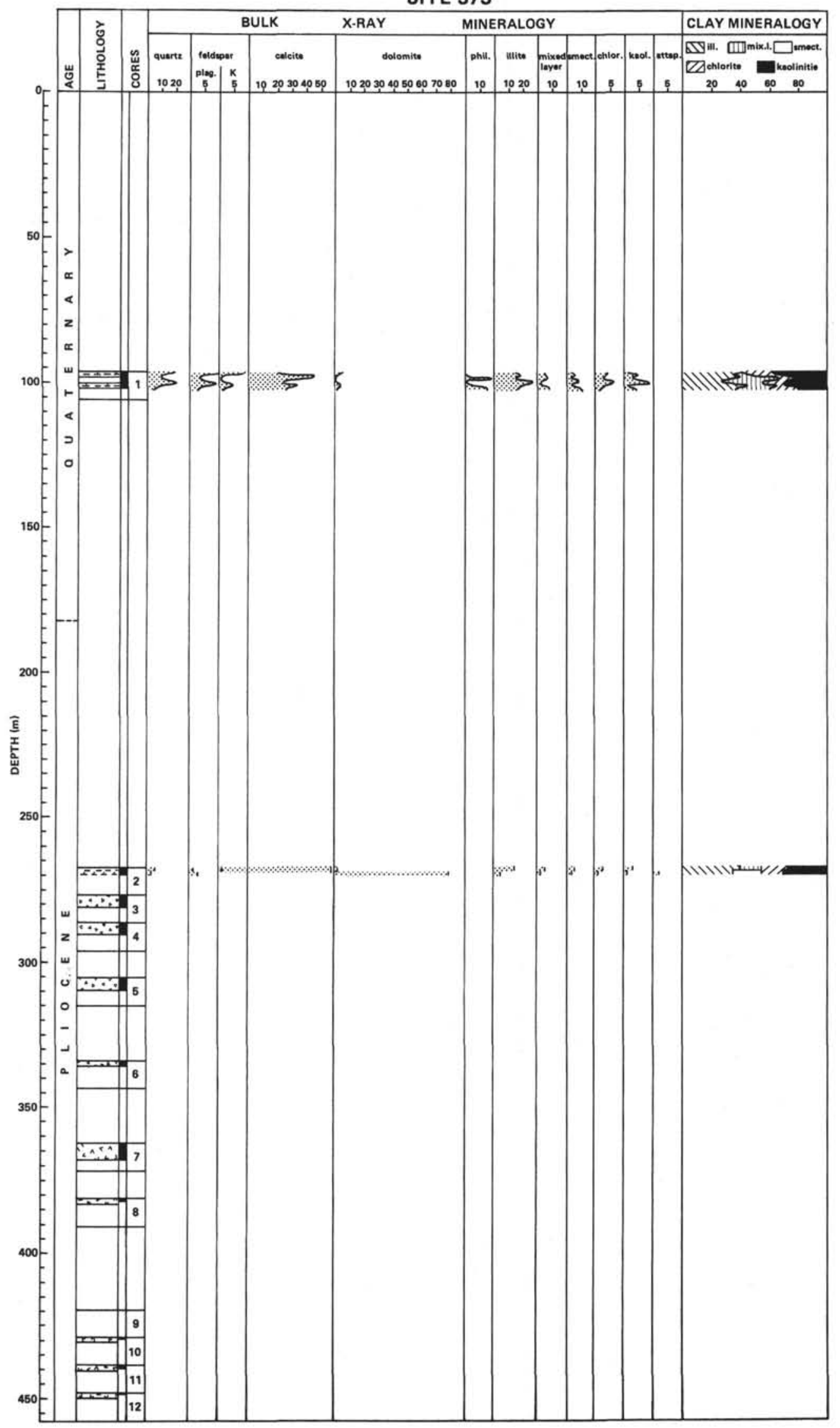

Figure 4. X-ray mineralogy data, Site 373. 
fossil marls consist of calcite (25\% to $30 \%$ ), dolomite ( $1 \%$ to $3 \%$ ), quartz + feldspar ( $15 \%$ to $20 \%$ ), and clay minerals ( $45 \%$ to $55 \%$ ). Among these clay minerals (in bulk) illite is largely dominant $(50 \%)$, then smectite ${ }^{3}$ (15\%), chlorite $(15 \%)$, kaolinite $(15 \%)$, and minor amounts of mixed-layer clay. The zeolitic marls are characterized by phillipsite (up to $17 \%$ ), which seems to be superimposed on the background of nannofossil marls.

The nannofossil marls of Core 2 (early to late Pliocene, a condensed section) are very rich in calcite (up to $64 \%$ ) and consequently the quartz + feldspar + clay content is modest. The base of the core consists of a lithified red dolomitic marl characterized by a very high dolomite content $(80 \%)$. The high calcium content of this dolomite $\left(\mathrm{Ca}_{56}\right)$ and the total lack of calcite suggest that the dolomite is probably diagenetic, having replaced calcite (oxygen isotope data support this hypothesis [Bernoulli et al., this volume]).

The marked contrast in the carbonates/silicates ratio between Cores 1 and 2 suggests that the depositional environment during the Quaternary was significantly different from that during the Pliocene. The low terrigenous material content of the Pliocene sediments suggests that this material could hardly reach the area (Site 373), probably because of inhibited water circulation. Because of a physiography consisting of several small basins, more or less separated by barriers. In the Quaternary sediments the considerable terrigenous detrital content (up to $70 \%$ of the sediment, quartz + feldspar up to $4.5 \%$ ) implies much better conditions for transportation, which could indicate the existence of steeper continental slopes. In this hypothesis, a notable deepening of the basin occurred between Pliocene and Quaternary, probably related to the lowering of the floor of the Tyrrhenian Sea. An active volcanism (ashes, zeolites) in the area seems to support this hypothesis. We should emphasize that these conclusions are obviously highly speculative because of the very low sampling frequency at this site.

\section{Site 374}

Site 374 is located in the central part of the Messina Abyssal Plain in 4078 meters of water. The hole penetrated a 457-meter section consisting of 300 meters of nannofossil marls and muds with numerous silty layers (Cores 1 to 4: Quaternary), 80 meters of highly carbonaceous nannofossil marls (Cores 5 to 11: Pliocene) and 77 meters of Messinian evaporites (mainly gypsum, anhydrite, and halite; Cores 12 to 24), whose upper 20 meters (Cores 12 to 15 ) consist of homogeneous dark dolomitic muds barren of stratigraphic fossils. Fifty-seven samples were submitted for X-ray analysis (Figure 5).

Evaporite rocks were not sampled for routine X-ray analysis. Their study (Garrison et al., this volume;

\footnotetext{
3 In the less than $2 \mu \mathrm{m}$ fraction, the absence of smectite is probably a question of terminology since this mineral has been labeled as irregular mixed-layer illite-smectite by the clay minerals analyst, because of its poor crystallinity.
}

Kuehn and Hsü, this volume) established that they have been deposited in shallow brine pools (halite) progressively desiccated and subaerially exposed (nodular anhydrite). The area was covered by shallow water bodies, from time to time, when gypsum, interbedded with dolomitic marlstones, was cyclically deposited.

The mineralogy of the dark gray dolomitic muds (Cores 15 to 12 ) overlying the evaporites is rather uniform. It consists of quartz + feldspar ( $15 \%$ to $20 \%$ ), clay minerals ( $55 \%$ to $70 \%$ ), and dolomite ( $15 \%$ to $25 \%)$. The striking lack of calcite, together with the high calcium content of the dolomite $\left(\mathrm{Ca}_{55}\right)$, suggest that this latter mineral was diagenetically formed by "replacement" of a calcitic fraction probably of biogenic origin; this diagenesis is associated with interstitial water extremely rich in magnesium (McDuff and Gieskes, this volume). White millimetric spheres are disseminated in the sediment from place to place. They were not submitted for routine X-ray analysis, but were shown to consist of lüneburgite (magnesium borophosphate; Müller and Fabricius, this volume). The mineralogy of the clays is of special interest. In the bulk, illite is the dominant mineral (20\% to $25 \%$ ) followed by smectite ( $15 \%$ to $20 \%$ ) and irregular mixed-layered illite-smectite $(10 \%)$ considered to be illite-derived, and minor amounts of chlorite $(7 \%)$ and kaolinite (5\%). In constrast, the less than $2 \mu \mathrm{m}$ fraction is largely dominated by smectite $(50 \%$ to $75 \%$ ) followed by chlorite; illite is subordinate $(15 \%)$ and kaolinite $(5 \%$ to $10 \%$ ) fills up the assemblage. These facts suggest that the dark gray dolomitic muds developed essentially from a terrigenous input ( $75 \%$ to $85 \%$ of the sediment) which settled in calm conditions (clay minerals dominant in the bulk; smectite - the finest particles - dominant in the less than $2 \mu \mathrm{m}$ fraction). Furthermore, the depositional environment was unfavorable for the biota, as suggested by the low carbonate content (the total lack of calcite probably results from a post-depositional dolomitization as will be seen further, although a very early dolomitization is not impossible).

Overlying the dark gray dolomitic muds of the uppermost Messinian, the 80 -meter-thick Pliocene section (Cores 11 to 5 ) displays a remarkable homogeneity in its mineralogy, except in the extreme base (Core 11) which is of diagenetic origin, as will be discussed below. The dominant features are (a) a very high carbonate content $(60 \%$ to $70 \%)$, (b) a very low quartz + feldspar content ( $5 \%$ to $10 \%)$, and (c) a moderate clay content. The mineralogy of the clay assemblage is characterized by the presence of attapulgite which constitutes up to $50 \%$ of the less than $2 \mu \mathrm{m}$ fraction (although its contribution to the bulk never exceeds $5 \%$ ). This mineral has been shown to be derived from North Africa (Chamley, 1971). With regard to the underlying dark dolomitic muds, the smectite/illite ratio decreases markedly in the less than $2 \mu \mathrm{m}$ fraction and even more in the bulk. The carbonate fraction consists mainly of calcite (nannofossils and foraminifers) and minor amounts of calcium-rich dolomite $\left(\mathrm{Ca}_{55}\right)$, except in Core 11. In this core, subjected to an 
SITE 374

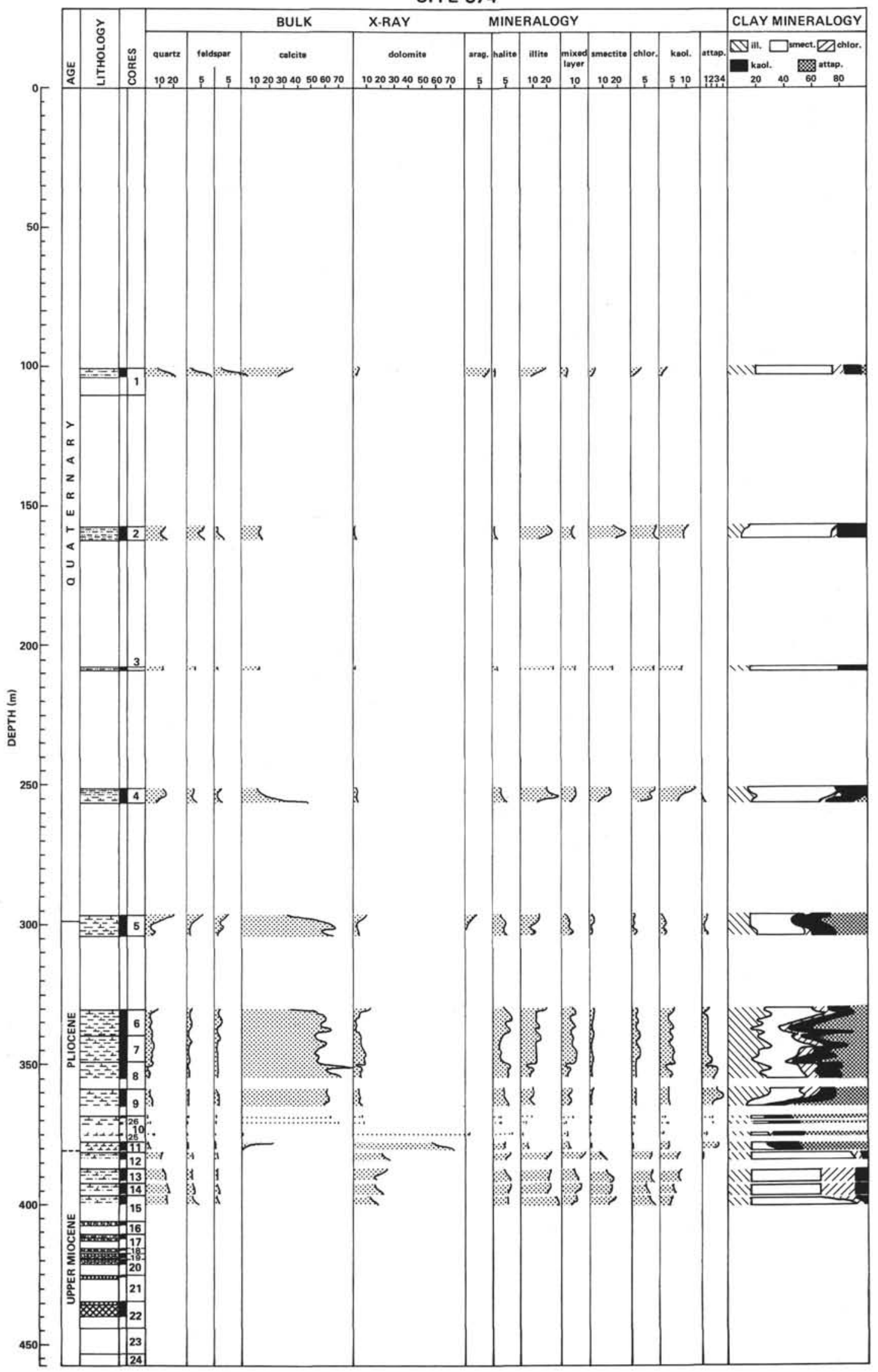

Figure 5. X-ray mineralogy data, Site 374. 
especially detailed X-ray and SEM study by Bernoulli and Mélières (this volume), an intense dolomitization caused by interstitial water extremely rich in magnesium has completely replaced the calcitic biogenic material (McDuff and Gieskes, this volume). The calcium content of the dolomite ranges from $\mathrm{Ca}_{53}$ to $\mathrm{Ca}_{55}$, and the mineral exhibits a very unusual morphology consisting of pseudohexagonal flakes, up to $40 \mu \mathrm{m}$ across, with well-developed (001) crystal faces. On the X-ray diffractograms, the (001) reflections are considerably enhanced (the [006] peak intensity is similar to that of the [104] peak). The amount of dolomite (plus some calcite remains at the top of the core) is very constant all along the core and similar to the amount of calcite (plus minor amounts of dolomite) in all the overlying Pliocene section. This, together with the nature of the clay mineral assemblage characterized by attapulgite, indicates that Core 11 belongs lithologically to the Pliocene. The sidewall Core 25, taken 3 meters above Core 11, displays essentially the same mineralogy. In contrast, in sidewall Core 26, taken 4 meters above sidewall Core 25, the mineralogy is identical to that of the overlying nannofossil marls (calcite $70 \%$ ). Therefore the "front of dolomitization" can be located between the two sidewall cores (371-375 m below the sea floor).

The mineralogy of the Pliocene section (Cores 11 to 5 ) indicates that the deposition of the highly calcareous nannofossil marls resulted from the establishment of "normal marine" conditions in the basin, following the stressed environment existing during the upper Messinian (dark gray dolomitic muds). The appearance of attapulgite indicates that the Pliocene sea was able to carry a terrigenous material from North Africa. The fact that this material is almost devoid of a "coarse fraction" (quartz + feldspar content ranges from 5\% to $10 \%$ ) suggests either that the surrounding landmasses did not generate such a "coarse" material, or more likely that this "coarse" material could not reach the area (Site 374) because of the rather gentle character of the slopes of the basin. In this latter hypothesis the basin would have been relatively shallow with regard to the present physiography. The infilling of the area by seawater is tentatively understood as the result of a moderate raising of the water level, allowing the shoreline to reach the African "coast."

On the basis of the variations of the clay mineral assemblage in the less than $2 \mu \mathrm{m}$ fraction, the Pliocene section can be divided into two parts. In the lower part (Core 11 to Core 9, Section 4), attapulgite is largely dominant (50\% to $55 \%$ ), suggesting that the terrigenous input is mainly derived from North Africa. This is in good agreement with the fact that, during the early Pliocene, Sicily, Calabria, and Pelopenese were only partially emerged (in Sicily and Calabria, the marine calcareous facies of the early Pliocene - "Trubi" - is well developed). Therefore these areas could not have acted as notable terrigenous sources. In the upper part (Core 9, Section 3 to Core 5), attapulgite is still present (average $30 \%$ ), but smectite (chiefly from Sicily) and chlorite (chiefly from Greece) increases significantly.
This change, occurring within the MPL-2 zone (about 4.5 m.y. B.P.) may be related to the compressional tectonic episode in the early Pliocene in the Peloponese (southwestern Greece) and Apulie (southeastern Italy) (Mercier, et al., 1976), and to uplifting phases in Sicily at the same time (Mascle, 1974).

The 300-meter-thick Quaternary sequence, only documented by four cores (Cores 4 to 1 ), shows very significant differences in mineralogy, to the Pliocene: (a) an increase in quartz + feldspar content (average $15 \%$, reaching $40 \%$ in Core 1 ); (b) a marked increase in clay mineral content (average $70 \%$, except in Core 1 : $20 \%$ ); (c) a notable decrease in carbonate content (average 15\%, reaching $40 \%$ in Core 1 due to aragonite contribution); (d) a disappearance of attapulgite, and (e) an increase in smectite which becomes the dominant mineral in the less than $2 \mu \mathrm{m}$ fraction. The disappearance of the North African contribution (attapulgite) to the terrigenous input can be explained in terms of dilution by the Sicilian and Calabrian detrital supply (smectite), the importance of which is probably related to two differential vertical movements: lowering of the Ionian Basin, accentuated in the northern part, and uplift of the Sicily and the Calabrian Arc, causing a tipping over towards the south and southeast. These relative moven ents are probably a consequence of the underthrusting of the European plate by the African plate, in this area (Ryan et al., 1971). A compressional tectonism, active in the early Quaternary, has been demonstrated in the external Aegean Arc (Mercier et al., 1976). As a result of these movements, the northwestern continental slope in the Ionian Basin became steeper allowing important downslope transportation of terrigenous material. At Site 374, the mineralogy of Core 1, characterized by quartz, feldspar, aragonite (produced on the shelf), and very well-crystallized illite (mica), illustrates remarkably well this type of sedimentation, the accumulation rate of rate of which is high (averaging $150 \mathrm{~mm} / 1000 \mathrm{yr}$ ).

\section{Resume}

a) Late Messinian: after deposition of evaporites in shallow ponds episodically submerged, dark dolomitic muds are deposited in a calm environment under unfavorable conditions for the biota.

b) Early Pliocene: infilling of the basin by rising of the water level until shoreline reached North African platform; basin was probably not very deep, as suggested by the low and very fine terrigenous input; establishment of "normal marine" conditions with welloxygenated environment; bloom of planktonic life, acting as source of high calcareous nannofossil marls, the base of which was later dolomitized.

c) Middle and upper Pliocene: within the MPL-2 Zone (about 4.5 m.y.B.P.), partial emergence of Sicily, Calabria and Peloponese; persistence of the early Pliocene physiography.

d) Quaternary: fast infilling of rapidly subsiding Ionian Basin with detrital material derived from uplifted landmasses. 


\section{Sites 375 and 376}

Sites 375 and 376 are located on the Florence Rise, about $40 \mathrm{~km}$ west of Cyprus. They complement one another and their results have been combined. Site 375 is a deep hole with spot coring, drilled near the top of the rise, on its southern flank, in 1900 meters of water. In order to investigate the pre-Messinian sediments, this hole was located in that part of the rise where these sediments subcrop beneath a veneer of PlioQuaternary sediments. The hole penetrated 135 meters of Plio-Quaternary sediments which were not cored, about 50 meters of Messinian evaporites (Cores 1 and 2), then a 400-meter-thick sequence of Tortonian (Cores 4 to 7), Serravallian (Cores 8 and 9), Langhian (Cores 10 and 11) age. It was terminated at 821.5 meters subbottom in the Burdigalian sediments (Cores 12 and 13). Fiftyone samples were submitted for X-ray analysis (Figure 6). Site 376 is located about $12 \mathrm{~km}$ north of Site 375 . It is on the northern flank of the Florence Rise, near the pinch-out of the salt layer of the southern margin of the Antalya Basin, in 2101 meters of water. The hole, which was cored almost continuously for 216.5 meters subbottom, penetrated about 55 meters of Plio-Quaternary nannofossil marls (Cores 1 to 6), 80 meters of upper Messinian turbidites (Cores 7 to 15) consisting of nannofossil marlstones dolomitic in the upper part (Cores 7 to 11), and 80 meters into the upper Mediterranean evaporite formation (Cores 16 to 23) consisting mainly of gypsum and green dolomitic marlstones (Cores 16 to 20) and anhydrite and halite in the lowermost part (Cores 22 and 23). Thirty-six samples were submitted for X-ray analysis (Figure 7).

Before discussing the mineralogical data, it is necessary to briefly outline the structural framework of the western part of Cyprus, with emphasis on petrology and mineralogy of the outcropping rocks and their detrital products. The southwestern part of Cyprus, which is the largest part of the island, is chiefly made up of the Troodos Massif. It consists (Desprairies and Lapierre, 1973) of a core of peridotites and gabbros surrounded by a complex of doleritic and ophitic intrusions; a thick volcanogenic sequence (pillow-lavas, sills, dykes and pyroclastics) belts the system, and the whole displays numerous features of ophiolites. All these rocks have been extensively altered, mostly by early hydrothermal processes, and their detrital products have been accumulated and reworked around the Troodos Massif. The mineralogy of these deposits, mainly Upper Cretaceous in age, is everywhere strikingly dominated by smectites, constituting at times up to $100 \%$ of the clay minerals. Smectites are often associated with clinoptilolite. Attapulgite has been found in significant amounts. On the southwestern edge of Troodos, some sediments consist almost exclusively of regular mixed-layer types such as corrensite (65\%) and allevardite $(20 \%)$. It is obviously beyond the scope of the present work to give more detailed information on the mineralogy of West Cyprus. Nevertheless, the brief mineralogical data outlined here are very important, because Sites 375 and 376 are located in the immediate vicinity of Cyprus. South Turkey, although more distant from the Florence Rise than Cyprus is, may have acted as source of terrigenous material. In this area, ophiolites are well developed too, and display similar mineralogy to that of Cyprus ophiolites.

The mineralogy of the pre-Messinian sediments (Site 375) is rather uniform suggesting that, on the whole, the conditions of sedimentation did not change very much (Figure 6).

The Burdigalian marlstones, documented by only one sample (Core 13) are characterized by a high clay mineral content ( $63 \%$ of the bulk), dominated by smectite $(30 \%)$ and well-crystallized kaolinite $(20 \%)$, calcite (24\%), and quartz (12\%). No feldspar is detectable in the bulk. This suggests that the marlstones were derived from a terrigenous material highly weathered under a rather warm and humid climate.

The Langhian sediments (Cores 11 and 10) display various lithologies. Nevertheless they are characterized by a high carbonate content (average $60 \%$ ) and a very low quartz content (3\%). Plagioclase feldspar occurs as traces. Carbonates consist mainly of calcite reaching $96 \%$ in white foraminifer limestone. Calcium-rich dolomite $\left(\mathbf{C A}_{56}\right)$ is present in significant amounts (up to $19 \%$ ) together with attapulgite (up to $11 \%$ ) in the reddish and greenish marlstones, suggesting that some diagenesis occurred in this facies. Smectite dominates the clay mineralogy, sometimes accompanied by kaolinite, which could indicate the influence of a warm climate during this period. The reddish and greenish marlstones were deposited in a very calm marine environment, receiving at times a biogenic detrital input.

The Serravallian marlstones (Cores 9 and 8) are characterized by a higher terrigenous content than those of the Langhian. Feldspar occurs significantly, being sometimes as abundant as quartz (up to $8 \%$ ). The clay mineral content increases markedly, due to illite and chlorite contribution; nevertheless smectite remains dominant. The less than $2 \mu \mathrm{m}$ fraction, dominated by smectite $(70 \%)$, does not display marked change, suggesting the persistence of terrigenous sources. The importance of smectite and the presence of serpentine (up to $2 \%$ ) leave little doubt as to the ophiolite origin of the terrigenous input which is probably derived from Cyprus. The increase in quartz, illite, and chlorite (the coarsest clay particles), indicates more active transportation of terrigenous material. The extreme variations in calcite content $(0 \%$ to $78 \%$ ) can only be understood if the sediments devoid of calcite were sampled in turbidites consisting of very fine terrigenous material. Sediments very rich in calcite indicate that, between the periods of turbidity current activity, the depositional conditions were calm, allowing the settling of calcareous biogenic production. The fact that these turbidites consist of very fine particles (in Sample 8-5, 69-72 cm calcite content is $1 \%$ and clay content is $85 \%$ ) can be explained either by the weakness of turbidity currents, or more likely by the location of Site 375 on the flank of Florence Rise, which meant that only the finest particles reached the site. The 
F. MÉLIÈRES, H. CHAMLEY, F. COUMES, P. ROUGE

SITE 375

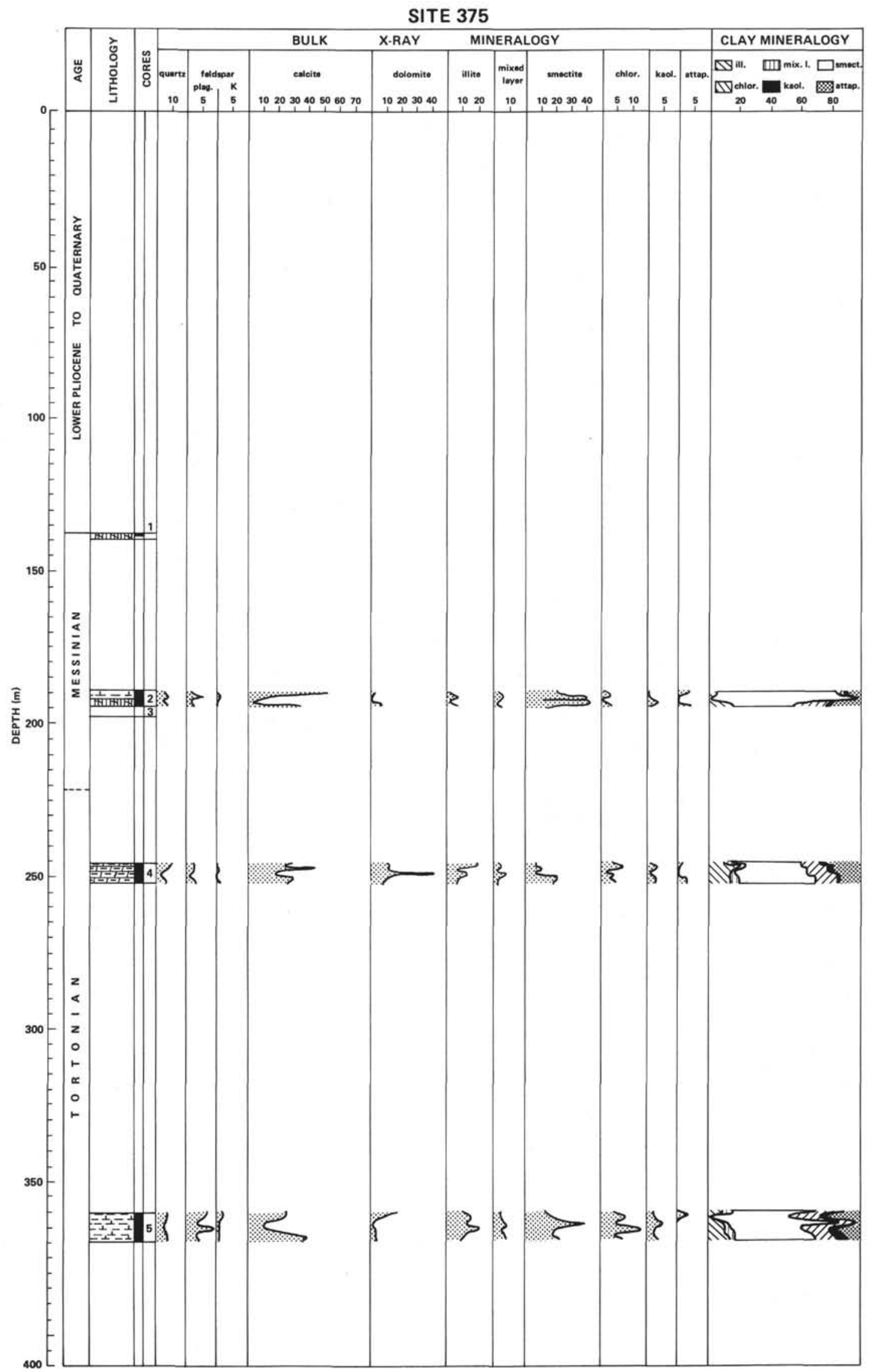

Figure 6. X-ray mineralogy data, Site 375 . 
SITE 375

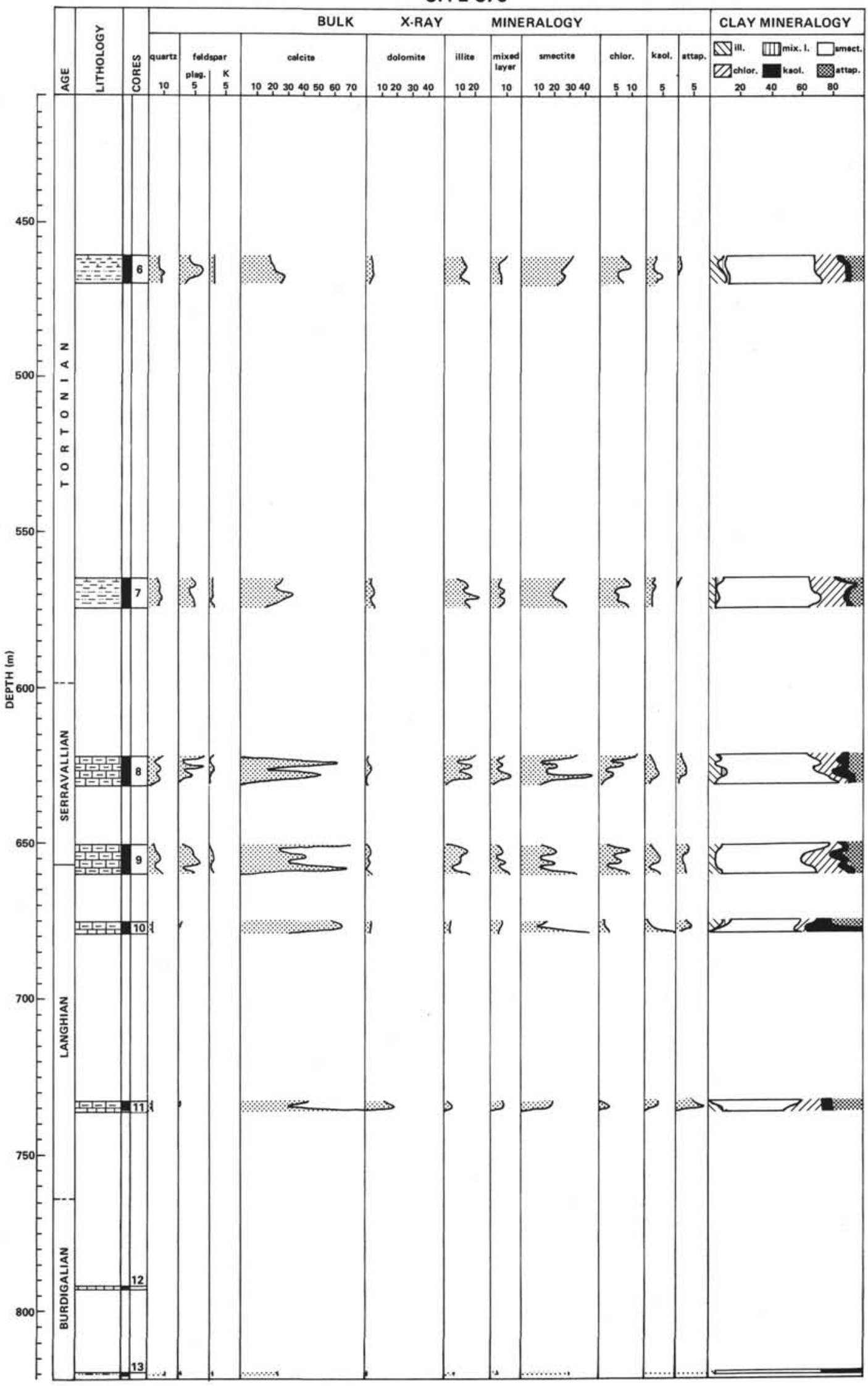

Figure 6. (Continued). 


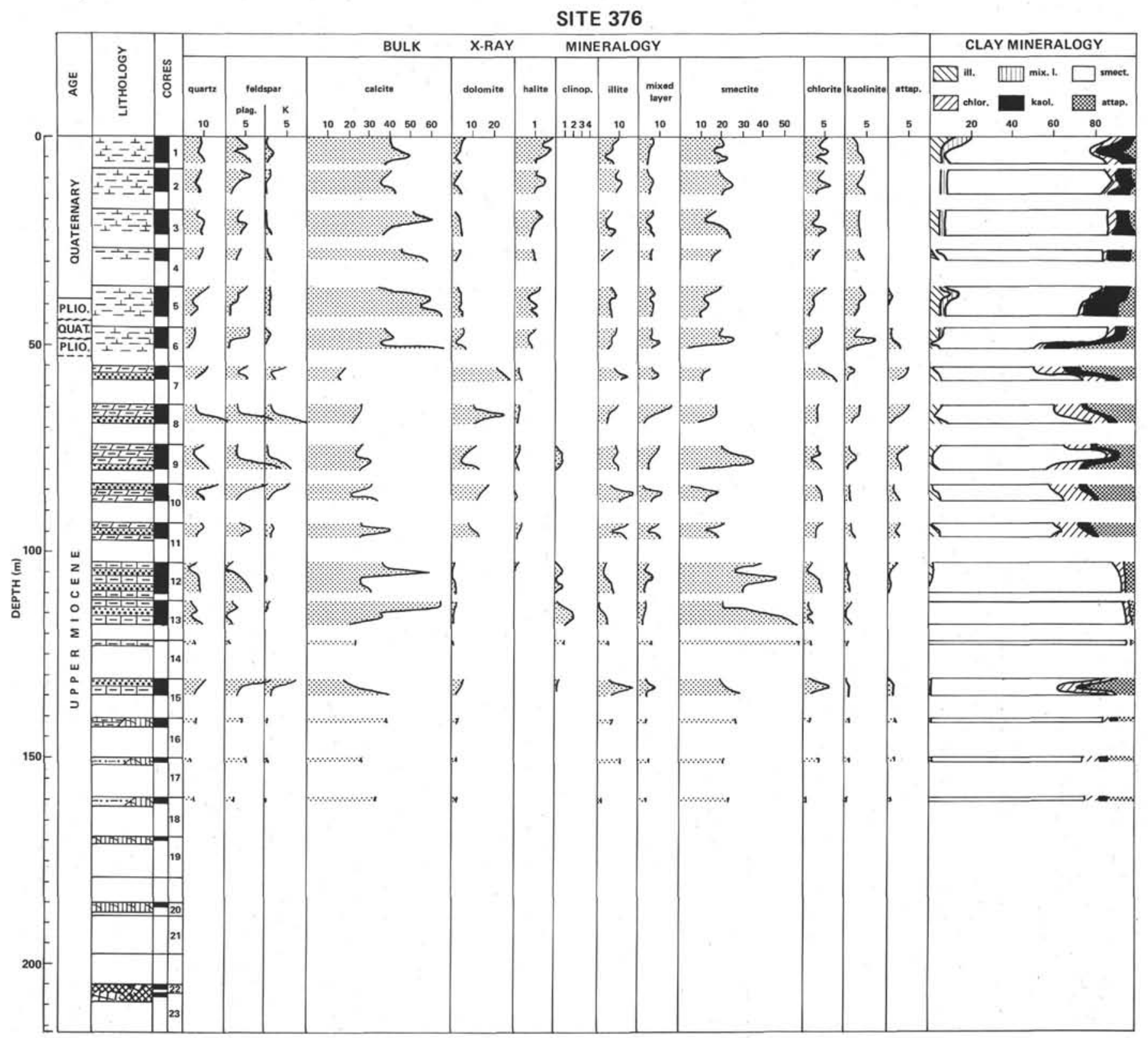

Figure 7. X-ray mineralogy data, Site 376.

presence of turbidites implies the existence of continental slopes (Cyprus lies $40 \mathrm{~km}$ eastward), suggesting that the water depth was not negligible.

In the Tortonian (Cores 7 to 4 ), there is no fundamental change in the mineralogy of the sediments with regard to the Serravallian. Smectite dominates the clay mineral assemblage in the less than $2 \mu \mathrm{m}$ fraction as well as in the bulk. Serpentine is still present. Nevertheless several differences are noticeable. The calcite decreases markedly and the range of its variations ( $10 \%$ to $45 \%$ ) is less important than in the Serravallian ( $0 \%$ to $78 \%$ ). This is in good agreement with the fact that the thick $(400 \mathrm{~m})$ Tortonian section (high sedimentation rate) consists essentially of turbidites. Consequently, the active settling of terrigenous material precluded high carbonaceous sedimentation, although the depositional environment probably remained the same. The sedimentation during the Tortonian evidences orogenic activity on Cyprus and probably on South Turkey, inducing pronounced erosion of landmasses. This is supported by the appearance, among clay minerals, of small but noticeable amounts of corrensite (mixedlayer chlorite-smectite), which is known to exist on Cyprus in pyroclastics of the southern flank of the Troodos Massif (Desprairies and Lapierre, 1973). At the top of the Tortonian section (Core 4), illite and attapulgite increase in the less than $2 \mu \mathrm{m}$ fraction and dolomite in the bulk (values ranging mostly from $10 \%$ to $15 \%$, maximum $43 \%$ ). The dolomite is calcium-rich $\left(\mathrm{Ca}_{55}\right)$ and a very fine grained (clay size). This suggests some change in the nature of the detrital input. This change could be related to the very beginning of a 
regional environmental restriction (increase in magnesium), leading later to the deposition of the upper Miocene evaporites (Messinian). Such restricted environments would have been preferentially developed nearshore in shallow-water areas, where dolomite (and attapulgite ?) would have grown. This phenomenon is probably related to the beginning of lowering of the sea level. The occurrence of gypsum as corroded monocrystalline flakes (detrital) within the sediments of Core 4, indicates that gypsum was grown at (or even before) that time in areas acting as detrital material sources. This suggests a gradual increase of confinement in near-shore areas during the end of the Tortonian, supporting the hypothesis of a very progressive onset of the upper Miocene "salinity crisis."

The Messinian evaporite rocks were not sampled for $\mathrm{X}$-ray analysis. Although poorly sampled by spot coring at Site 375, they are well documented in the Upper Member, by seven cores at Site 376 (Cores 16 to 23). They are interpreted as shallow water deposits (Garrison et al., this volume; Kuehn and Hsü, this volume).

The post-evaporite sequence, cored continuously at Site 376 (Figure 7), displays numerous variations in its mineralogy. A very accurate survey of the halite content of the sediment (this halite is obviously "secondary" and results from the evaporation of the interstitial water in the laboratory when the samples are dried) was carried out, in order to attempt to characterize the paleosalinity of the depositional environment. Indeed the salinity of interstitial water does not necessarily reflect the salinity of the water trapped in the newborn sediment. Nevertheless this approach was encouraged by previous results gained from various Plio-Quaternary sequences deposited in well known "normal marine" conditions.

On the basis of the mineralogical assemblages, the 80 -meter-thick section of nannofossil marls (mainly turbidites) overlying the Messinian evaporites, can be divided into two parts. The lower part (Cores 15 to 12) is characterized by a calcite content displaying very important variations ( $20 \%$ to $60 \%$ ), a very low dolomite content (average 1\%), and a clay content strongly dominated by smectite (reaching almost $100 \%$ of the less than $2 \mu \mathrm{m}$ fraction). Clinoptilolite, known in pyroclastics on western Cyprus, correlates very well with smectite. This, together with the presence of welldeveloped turbidites, indicates that intense transportation of terrigenous material from Cyprus occurred frequently. Because of the lack of "secondary" halite (see statement above) in the sediment (less than $0.1 \%$ ), it is thought that the terrigenous input was deposited in a fresh (or nearly fresh) water body. ${ }^{4}$ The existence of

${ }^{4}$ The presence of a fresh (or near fresh) water body in the basin at that time would probably have induced the existence of fresh water aquifers in the pre-Messinian sediments of the Florence Rise. Curiously, these sediments, as deep as investigated at Site 375 (Burdigalian, $821 \mathrm{~m}$ subbottom), are completely devoid of "secondary" halite. This fact may be understood if the pre-Messinian sediments (obviously settled in "normal marine" conditions) had been leached by such fresh waters during the upper Messinian. a fresh or nearly fresh water body in the upper Messinian of Site 376 is supported by the fact that the carbonate fraction consists essentially of reworked nannofossils and foraminifers from Cretaceous to middle Miocene (see Site Report, Chapter 6). The upper part (Cores 11 to 7 ) is characterized by significant amounts of dolomite (4\% to $28 \%$ ), increasing towards the top of the section, and a noticeable contribution of attapulgite (long and well-developed fibers) and chlorite in the less than $2 \mu \mathrm{m}$ fraction, which, however, remains dominated by smectite. In Core 9, a major peak of smectite abundance correlates with the appearance of clinoptilolite. Calcite decreases towards the top of the section, both in content and in its variations. In this upper part, turbidites are less important than in the lower part (Cores 15 to 12). In the hypothesis that turbidites were triggered by changes in the water level, the decrease of calcite could suggest that the intensity of these changes, decreases significantly, allowing the development near-shore of some magnesium-rich pools where magnesium-rich minerals (dolomite, attapulgite, and chlorite) could have been generated. With regard to the lower part (Cores 15 to 12), "secondary" halite is detectable in the sediments in amounts which, combined with the water content, yield "salinity" values around $10 \%$. This would indicate that the previous fresh water environment became brackish by "marine" water influxes, possibly responsible for the magnesium paragenesis of this section. These influxes could have preceded the Pliocene transgression.

The Plio-Quaternary section (Cores 6 to 1 ), although disturbed at the base by slumping, displays a rather uniform mineralogical assemblage, roughly similar to that of present-day sediments. In contrast to the underlying upper Miocene sediments, the calcite content is high and ranges between $40 \%$ and $60 \%$. The highest values are recorded in the Pliocene (Core 5). The clay mineral assemblage is dominated by smectite ( $20 \%$ in the bulk), which constitutes $80 \%$ of the less than $2 \mu \mathrm{m}$ fraction, a value sensibly higher than in the immediately underlying Messinian sediments. The attapulgite content decreases markedly and the kaolinite content shows the highest values recorded at this site, especially in the Pliocene (Core 5). The prominence of both calcite (autochthonous biogenic production; see Site Report, Chapter 6) and kaolonite in Core 5 could suggest a warm climatic influence during the Pliocene. At the base of the Plio-Quaternary section, the "secondary" halite content (see statement above) marks a sharp break, and, combined with the water content, yields "salinity" values ranging from $30 \%$ o to $35 \%$ 。 all along the section. This suggests that "normal marine" conditions were re-established at the start of the Pliocene. The high smectite content indicates that ophiolites remain the chief source of terrigenous material. The upper Pleistocene sediments display, in the less than $2 \mu \mathrm{m}$ fraction, slightly higher chlorite and irregular mixed-layer contents than the lower Pleistocene sediments. This could be related to some minor change either in location of terrigeneous sources, or in the physiography of the basin due to tectonic activity. 


\section{Resume}

The dominant character of the sedimentation on the Florence Rise is the prominent contribution of minerals from ophiolite terrains (mainly Cyprus and possibly southern Turkey) to the terrigenous detrital input, as demonstrated by the constantly high smectite content of the sediments (smectite is by far the chief constituent in West Cyprus soils and sediments). This is not surprising since Sites 375 and 376 are located very close to the island.

a) Burdigalian-Langhian: settling of high calcareous biogenic production in calm depositional conditions; discrete terrigenous input of clayey material, indicating warm and humid climatic influences; inability, for "coarse" terrigenous material input to reach the site, indicates that the physiography was already similar to that of the present (rise).

b) Seravallian: persistence of previous conditions, occasionally disturbed by weak turbidity currents.

c) Tortonian: increase in turbidity current frequency, possibly related to a tectonic activity; thick sedimentary section deposited in late Tortonian probable beginning of sea level lowering preceding the onset of the upper Miocene "salinity crisis."

d) Upper Miocene: deposition of Messinian evaporites in shallow water; infilling of the area by fresh to brackish waters; extensive transportation of terrigenous material by turbidity currents, possibly triggered by changes in the water level. In the last part of this episode discrete influxes of "marine waters inducing magnesium-rich mineral paragensis near-shore probably occurred.

e) Pliocene: area invaded by seawater; rapid establishment of "normal marine" conditions; possible warm climatic influence favoring the calcareous biogenic productivity.

f) Quaternary: no drastic change in sedimentation; possible slight variation in the physiography of the basin (deepening ?) in upper Pleistocene.

\section{Site 377}

Site 377 is located in a cleft on the Mediterranean Ridge, previously drilled by Leg 13 (Site 126), in 3718 meters of water. The hole penetrated a 263-meter-thick sequence consisting of Quaternary sediments overlying disconformably a middle to lower Miocene section. The recovery of the disconformity at 193 meters subbottom is a drilling artifact; the change in lithology occurred at 161 meters as is evidenced by a change in drilling characteristics. Four cores were taken, and only six samples were submitted for X-ray analysis (Figure 8).

The Quaternary (lower Pleistocene) sediments (Core 1, Sections 1 and $2,142 \mathrm{~cm}$ ) consist of nannofossil marls, sapropels, tephras, sand with graded bedding, and slump breccias (implying reworking by bottom currents). Two samples were taken in the finest lithologies. Their mineralogy is characterized by a high calcite content ( $33 \%$ to $52 \%$ ) and a moderate terrige- nous input, dominated by illite ( $14 \%$ to $24 \%)$ and quartz + feldspar ( $12 \%$ to $17 \%$ ). Illite constitutes half of the less than $2 \mu \mathrm{m}$ fraction, followed by kaolinite, chlorite, and smectite. Because of complex reworking by bottom currents, this minerological assemblage does not necessarily reflect the initial consititution of the sediment (closely-spaced sampling would have been more suited to such variable lithologies). No sample from the base of Core 1, Section 2 (middle Miocene) was submitted for X-ray analysis.

Nannofossil marlstones of Core 2 (middle Miocene [Serravallian ?]) offer a mineralogical assemblage very similar to that of the Pleistocene sediments, suggesting that they could have acted as sources for the latter. This would indicate an active submarine erosion of the walls of the cleft during the lower Quaternary. Dark siltstones of Core 3 (middle Miocene) are characterized by a conspicuously low carbonate content (calcite $2 \%$ ). This suggests that they were deposited either by turbidity currents (masking the calcareous, biogenic production) or in an abiotic environment. Combination of these two possibilities is probable since a noticeable amount of pyrite $(4 \%)$ is present, and cross-lamination and faint grading occur. The terrigenous input is strongly dominated by smectite $(45 \%)$ and kaolinite $(13 \%)$. These two minerals are generally mutually exclusive, from a pedogenetic point of view. Therefore the polygenic character of this material can be explained by the influence of different landmasses acting as sources of terrigenous material, or by a polygenic character of the detrital material developing ashore. Core 4 consists exclusively of a drilling breccia of material similar to that of Core 3. Consequently, the mineralogical data have to be viewed with caution. Nevertheless, with regard to the data of Core 3 , they show a considerable increase in coarse particles (quartz, feldspar, illite, and chlorite) at the expense of the fine (smectite and kaolinite). The different ratio between these minerals within the same size class, keep approximately the same values. This would confirm turbidity current sedimentation. The presence of pyrite also confirms the abiotic character of the medium: this allows the interpretation of the calcite as a terrigenous detrital component. Serpentine, present in small amounts, indicates that the terrigenous material probably originates from ophiolites of the external Aegean Arc. In this hypothesis, smectite would proceed from the same origin. Again these conclusions are of a highly speculative character because of very poor sampling frequency.

\section{Site 378}

Site 378 is located on the northern flank of a small depression in the North Cretan Basin of Aegean Sea, in 1835 meters of water. Two holes (378 and 378A) were drilled at the same location. The 343.5-meterthick section penetrated consists of nannofossil marls and oozes of Quaternary age (Core 1, Hole 378A; Cores 1 to 5 , Hole 378), nannofossil marlstones with sapropel layers of Pliocene age (Cores 6 to 11, Hole 378; Core 3, Hole 378A), and massive selenitic gyp- 


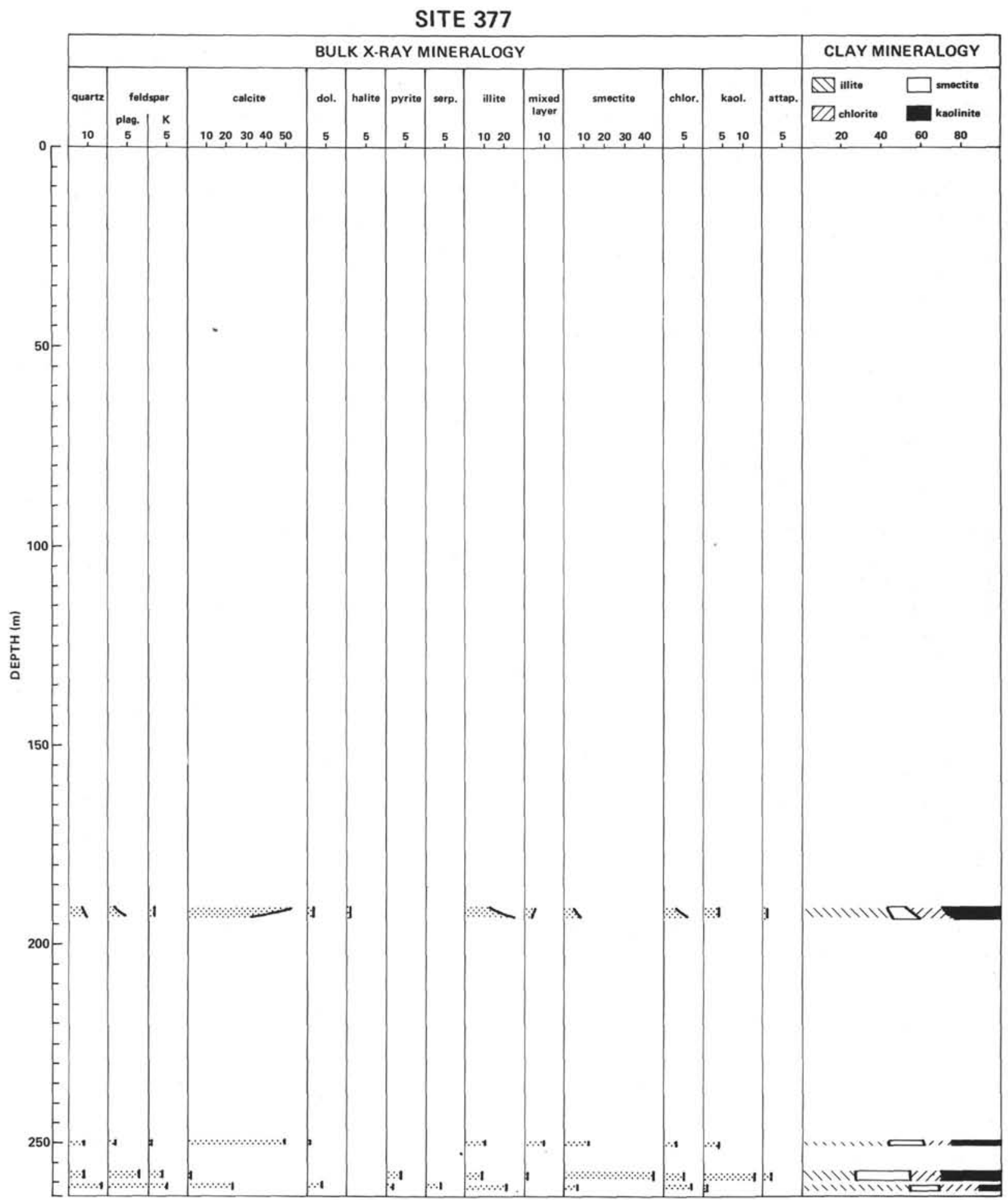

Figure 8. X-ray mineralogy data, Site 377.

sum topped by a brecciated and vuggy dolomite, of late Miocene age (core catcher 11, Hole 378; Cores 4 to 9 , Hole $378 \mathrm{~A}$ ). Thirty-three samples were submitted for X-ray analysis (Figure 9).

The mineralogy of the whole section (except the late Miocene evaporites not investigated by XRD) is remarkably uniform in the bulk as well as in the less than $2 \mu \mathrm{m}$ fraction. Calcite, averaging $40 \%$, is the dominant mineral, with minor amounts $(5 \%)$ of $\mathrm{Mg}$ calcite $\left(10 \% \mathrm{MgCO}_{3}\right)$ occurring in Core 1, Hole 378A (Quaternary). Dolomite content is low (average 5\%); this mineral is always calcium-rich $\left(\mathrm{Ca}_{54-56}\right)$, except in Core 1, Hole 378A, where it is stoichiometric. Quartz + feldspar content ranges from $10 \%$ to $15 \%$. In the 
less than $2 \mu \mathrm{m}$ fraction, illite dominates the clay mineral assemblage with values ranging from $40 \%$ to $50 \%$; smectite, chlorite, and kaolinite, in approximately equal amounts, complete this assemblage. Serpentine is present everywhere in very small amounts (average $1 \%)$; its content is slightly higher in the early Pliocene sediments ( $2 \%$ to $3 \%)$.

This very monotonous mineralogical assemblage suggests that the sources of terrigenous and biogenic materials have not changed since the early Pliocene. The only slight variation occurs in Core 1 of Hole 378A (upper Pleistocene), where the appearance of $\mathrm{Mg}$ calcite (thought to be a shelf product) indicates a more pronounced detrital input. This is supported by the presence of stoichiometric dolomite (thought to be terrigenous) instead of calcium-rich dolomite (early diagenetic) occurring in the underlying sediments. A marked increase in plagioclase content towards the top of Core 1 (378A) seems to support this hypothesis. This change in detrital input may be explained by an active downslope transportation of the terrigenous material. This could result from a deepening of the basin. Foundering in the Aegean area during the Pleistocene is known to be a consequence of northnorthwest-south-southeast extensional tectonics (Mercier et al., 1976; Keraudren, 1975). Indications of these events appear to be recorded within Core 1, Hole $378 \mathrm{~A}$.

\section{COMPARISONS BETWEEN SITES}

\section{Pre-Messinian}

The Pre-Messinian sediments are documented at two sites: 372 on the Balearic Rise (western Mediterranean) and 375 on the Florence Rise (eastern Mediterranean). Despite similarities in the thicknesses and ages of the sedimentary sections ( 885 and $821 \mathrm{~m}$ respectively, both holes reaching the Burdigalian), the sedimentation differs completely between the two.

On the Balearic Rise, the Burdigalian sedimentation is dominated by a large terrigenous input consisting mainly of fine particles (clays and silts). Despite the nearness of Menorca, the terrigenous material appears to derive from far away continental sources, probably Alpine areas. This material was deposited at high sedimentation rates but also continuously, since there are no turbidites, in a marine environment. Free silica, probably supplied by a volcanic activity in the vicinity, allows radiolarians to develop. These conditions change abruptly within the uppermost Burdigalian: the hydrodynamism of the basin becomes rather subdued. Consequently the terrigenous input decreases markedly (although still deriving from the same sources) and this induces an increase in the carbonaceous biogenic contribution to the sediments. These conditions prevail during the Langhian, the Serravallian, and probably the Tortonian (see Bizon, Site Report, Chapter 3). The lowering of sea level (Messinian regression) causes an important erosion of the upper part of this sequence, while thick evaporites are deposited in the deepest part of the Balearic Basin.
Contrasting with this sedimentary history, the preMessinian sedimentation on the Florence Rise is strongly influenced by turbidity current activity. The terrigenous material originates from neighboring landmasses (Cyprus and possibly South Turkey), as is demonstrated by its high smectite content, this mineral being the chief constituent of soils (ophiolite derived) on Cyprus. After calm sedimentation during the Burdigalian and the Langhian, the activity of turbidity currents begins in the Serravallian and increases markedly in the Tortonian during which a thick sequence $(400 \mathrm{~m})$ is deposited. These turbidity currents are probably a consequence of tectonic activity on Cyprus and South Turkey. During the end of the Tortonian, a progressive trend towards restricted conditions leads to the upper Miocene evaporitic episode.

These two sections (372 and 375), although encompassing a similar time span, show fundamental differences appearing mainly in (a) the nature of the sources of terrigenous material and (b) the depositional environment. These differences obviously reflect their different physiographic locations (local as well as regional) and different structural histories of the areas in which they were drilled.

\section{Messinian}

Evaporite rocks were not submitted for routine $\mathrm{X}$-ray analysis. Therefore the comparisons involve only the upper Messinian sediments, which were recovered at Sites 371, 372, 374, and 376.

Sites 372 and 376 allow comparison of the upper Miocene sedimentation during the end of the Messinian Event, with that during the Pre-Messinian. At Site 372 the Messinian sediments are characterized by (a) an increase in quartz + feldspar + detrital dolomite content, while the clay mineral assemblage remains approximately the same, and (b) noticeable amounts of calcium-rich dolomite. At Site 376, the upper Messinian sedimentation is strongly influenced by terrigenous input. After the deposition of the evaporite rocks, the terrigenous input consists essentially of detrital calcite (reworked faunas from Cretaceous to middle Miocene) and detrital products derived from ophiolites (mainly smectite). These constituents are derived from neighboring landmasses (Cyprus). Calcium-rich dolomite and attapulgite, occurring in the upper part of the section, are tentatively interpreted as detrital constituents reworked from neighboring magnesium-rich environments, where these minerals were generated at approximately the same time. At both Sites 372 and 376 , the upper Messinian sedimentation is characterized, on the whole by (a) an influence of the terrigenous sources more pronounced than that during the pre-Messinian, and (b) the presence of magnesium-rich minerals.

The mineralogy of upper Messinian sediments from Sites 371 and 374 can only be compared with that of the Plio-Quaternary section, assuming the latter yields information on "open marine" sedimentation. At Site 371 , the upper Messinian sediments are characterized by (a) a higher coarse terrigenous content than the 


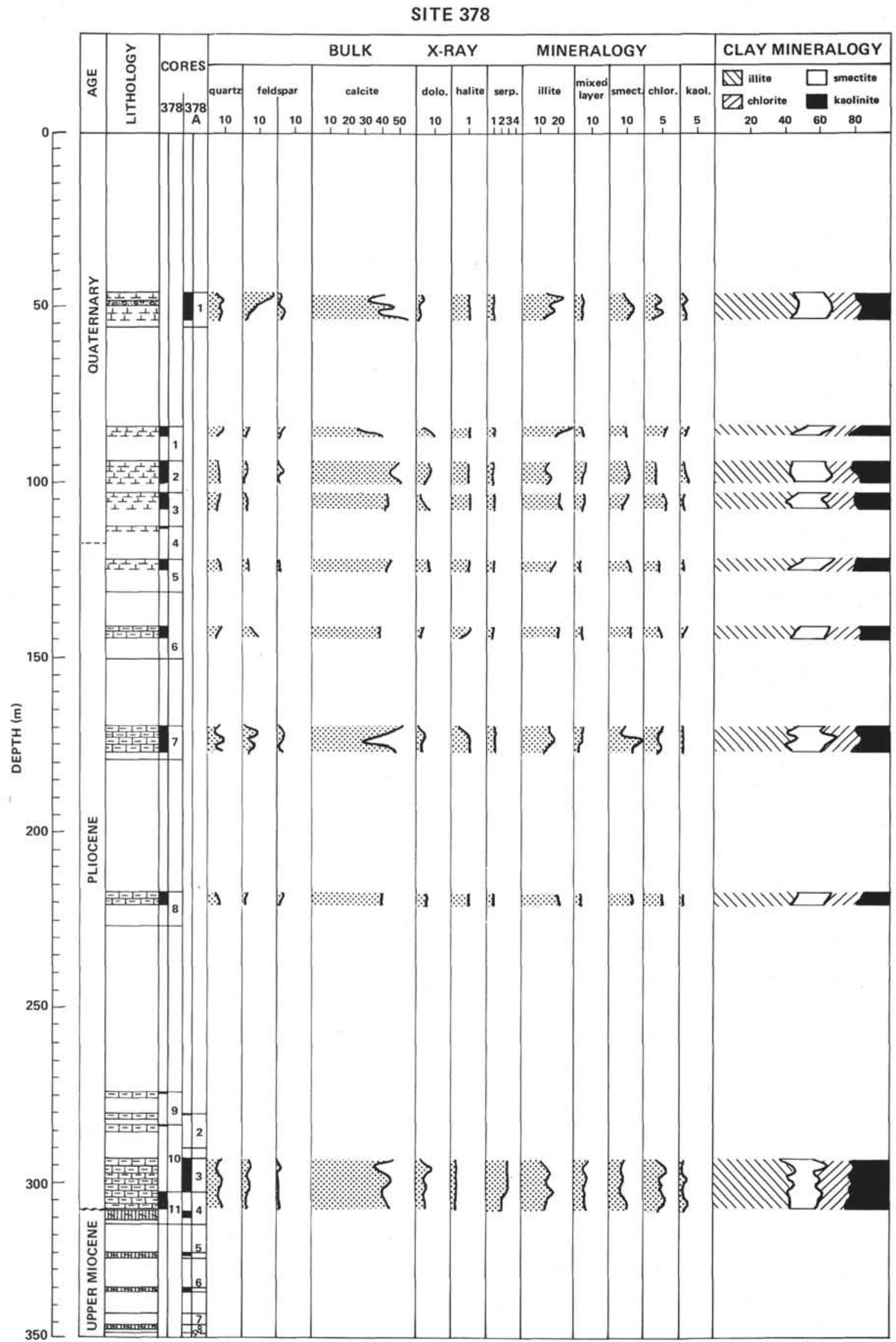

Figure 9. X-ray mineralogy data, Site 378. 
Plio-Quaternary sediments, and (b) significantly greater amounts of calcium-rich dolomite. The clay mineral assemblage is very similar to that of the PlioQuaternary sediments. At Site 374, the upper Messinian sediments are characterized by (a) a high terrigenous content, and (b) notable amounts of calcium-rich dolomite. In the less than $2 \mu \mathrm{m}$ fraction, the clay mineralogy differs fundamentally from that of the overlying Pliocene sediments, which are dominated by attapulgite (North Africa derived); however the Pliocene attapulgite occurs in minor amounts in the bulk (less than 5\%). The clay mineralogy of the upper Messinian sediments is comparable, in the bulk, with that of the Quaternary sediments, whereas in the less than $2 \mu \mathrm{m}$ fraction noticeable amounts of chlorite occur.

Sites 371 and 374 lead to conclusions similar to those drawn from Sites 372 and 376, concerning the upper Messinian sedimentation: (a) strong influence of the terrigenous material sources, and (b) presence of magnesium-rich minerals. Thus, although the mineralogy of the upper Messinian sediments displays notable discrepancies from one site to another because of discrepancies in the mineralogy of the terrigenous material sources, the sedimentation at that time is strongly marked by the two major features of the Messinian geodynamic event: changes in the water level and the existence of specific geochemical environments.

\section{Pliocene}

The Miocene-Pliocene contact was nowhere fully recovered. Nevertheless, data from Sites 372, 374, 376, and 378 provide useful information.

The Pliocene transgression at Site 374 (the most basinal location in the eastern Mediterranean) is distinct in the mineralogy of the sediments. High calcareous attapulgite-bearing nannofossil marls (the base of which was later dolomitized) overlie terrigenous dolomitic muds. The unrecovered transition is located somewhere within an interval at most 4.5 meters thick. The absence of a vertical trend between the facies indicates that this transition is probably sharp. At Site 376, despite a disturbance at the base of the Pliocene (a sedimentary slump), the transition is characterized by a sharp break in the mineralogy (at least on the scale of our sampling) and the appearance of a very high calcite content (biogenic production), while the terrigenous input displays a marked decrease. At Site 378, the Pliocene nannofossil marlstones overlie almost immediately massive selenitic gypsum (the undocumented interval is less than $1 \mathrm{~m}$ thick). In the eastern Mediterranean, the Pliocene appears to have a rather sudden onset, as far as it is documented by the three drill sites. Two of these sites are located in a basinal position ( 374 and 378 ) while the third is located on the flank of a rise (376).

At Site 372, the change from Messinian to Pliocene does not appear to the authors to have been a sudden event, and seems to result from several trends initiated during the end of the evaporitic episode (decreases in terrigenous input and in dolomite, increase in calcareous biogenic input). Except for the disappearance of smectite, no sharp break is recorded in the mineralogy. Although these variations are not continuously documented, due either to poor recovery of cores or to sedimentary gaps, the Pliocene transgression appears rather different at Site 372 than at the eastern Mediterranean sites. This is because Site 372 was not located in the deepest part of the basin when the Pliocene transgression occurred; but it could also be related to the fact that this transgression was more progressive in the western Mediterranean than in the eastern Mediterranean, thus the re-establishment of connection with the Atlantic Ocean resulted first in the replenishment of the Western Basin. The Eastern Basin, probably partly filled with fresh or brackish waters during the end of the Messinian, was not refilled with marine water until the sea level, in the Western Basin, reached the top of the Tunisian-Sicilian-Calabrian barrier.

The sedimentation during the Pliocene is very poorly documented in the western Mediterranean basins. At Site 372, the mineralogy of the Pliocene sediments, as compared to that of the pre-Messinian, suggests that a rather active hydrodynamism was established within the Pliocene. Such an active circulation could have resulted from a deepening of the basin. Site 371 yields similar information.

The Pliocene sedimentation was well documented at Sites 374 and 376 , and is characterized by a low terrigenous input, allowing a large contribution of the calcareous biogenic production. At Site 374, the sedimentation, partly influenced by North African sources, seems to record a compressional tectonic event that occurred within the Pliocene (MPl-2 Zone), partial emergence of the northern surrounding landmasses (Sicily, Calabria, and Peloponese).

Thus, a difference between Western and Eastern basins, in terms of hydrodynamism (and maybe of water depth), is indicated by the Pliocene sediments.

\section{Quaternary}

The mineralogy of the Quaternary sediments (poorly sampled at all sites except 376 ) is roughly similar to that of the Pliocene sediments, except at Site 374. At the latter site, the end of the Pliocene is characterized by (a) a notable increase in the terrigenous input, and (b) the disappearance of the North African contribution to this input. This change is related to the marked increase in amounts of detrital material supplied by the northern surrounding landmasses uplifted during the lower Quaternary, and to a deepening of the Ionian Basin. At the other sites, and as far as a very poor documentation allows, the Quaternary sedimentation as compared to that of the Pliocene, appears to be more active and/or to derive from a coarser terrigenous input. These characteristics suggest a general deepening of the basins and/or upliftings in landmasses. The latter are well documented by field geology in the borders of the Mediterranean, the physiography of which seems to have been significantly modified during the Quaternary. 


\section{ACKNOWLEDGMENTS}

The authors wish to acknowledge Dr. P. E. Biscaye (Lamont-Doherty Geological Observatory) and L. Montadert (Institut Erançais du Pétrole) for reading the manuscript and offering constructive criticisms. Technical assistance was provided by G. Giroud d'Argoud and J. Granger. The work was partly supported (clay mineralogy study of Sites 374, 375, and 376) by Grant CNEXO 75/5155.

\section{REFERENCES}

Biscaye, P. E., 1964. Distinction between kaolinite and chlorite in recent sediments by X-ray diffraction: Amer. Mineral, v. 49, p. 1281-1289.

Borg, I. Y. and Smith, D. K., 1969. Calculated X-ray powder patterns for silicate minerals: Geol. Soc. Am., Mem. 122.

Bourrouilh, R., 1973. Stratigraphie, sedimentoloqie et tectonique de l'ile de Minorque et du nord-est de Majorque (Baléares): Thèse, Université de Paris VI.

Brown, G., 1963. The X-ray identification and crystal structures of clay minerals: Mineralogical Soc., London.

Chamley, H., 1971. Recherches sur la sédimentation argileuse en Méditerranée. Sci. Géol. Strasbourg, Mém. 35.

Desprairies, A. and Lapierre, H., 1973. Les argiles liées au volcanisme du massif du Troodos (Chypre) et leur remaniement dans sa couverture: Rev. Géogr. Phys. Géol. Dyn., v. 15, p. 499-510.

Ferrara, G., Bigazzi, G., Bonadonna, F. P. and Giuliani, O., 1973. Radiometric dating of the Valencia volcanic rocks. In Ryan, W. B. F., Hsü, K. J. et al., Initial Reports of the Deep Sea Drilling Project, Volume 13; Washington (U.S. Government Printing Office), p. 773.
Johns, W. D., Grim, R. E., and Bradley, W. F., 1954. Quantitative estimations of clay minerals by diffraction methods: J. Sediment. Petrol., v. 24, p. 242-251.

Jones, J. B. and Segnit, E. R., 1971. The nature of opal: nomenclature and constituent phases: J. Geol. Soc. Australia, v. 18 , p. 57-68.

Keraudren, B., 1975. Essai de stratigraphie et de paléogéographie du Plio-Pléistocène égéen: Bull. Soc. Géol. France, v. XVII, p. 1110-1120.

Klug, H. P. and Alexander, L. E., 1967. X-ray diffraction prcedures: New York (John Wiley and Sons, Inc.).

Mascle, G., 1974. Les grands traits de l'évolution géologique des monts Sicani (Sicile). Bull. Soc. Géol. France, v. 16, p. 161-170.

Mauffret, A., Fael, J. P., Montadert, L., Sancho, J., and Winnock, E., 1973. Northwestern Mediterranean Sedimentary Basins from seismic reflection profile. Am. Assoc. Petrol. Geol. Bull., v. 57, p. 2245-2262.

Mélières, F., 1973. Porte-échantillon tournant pour analyse par diffractométrie X. Bull. Soc. franç. Min. Crist., v. 96, p. 75-79.

1974. Recherches sur la dynamique sédimentaire du Golfe de Cadix (Espagne): Thèse, Université de Paris VI.

Mercier, J. L., Carey, E., Philip, H., and Sorel, D., 1976. La néotectonique plioquaternaire de l'Arc égéen externe et de la mer Egée et ses relations avec la séismicité. Bull. Soc. Géol. France, V. XVIII, p. 355-372.

Ryan, W. B. F., Stanley, D. J., Hersey, J. B., Fahlquist, D. A., and Allan, T. D., 1971. The tectonics and geology of the Mediterranean Sea. In Maxwell, A. (Ed.), The Sea, v. 4: New York (John Wiley and Sons; Intersciences, p 387. 